\title{
Risk Taking and Interest Rates: Evidence from Decades in the Global Syndicated Loan Market
}

Lee, Seung Jung, Lucy Qian Liu, Viktors Stebunovs

Please cite paper as:
Lee, Seung Jung, Lucy Qian Liu, Viktors Stebunovs (2017).
Risk Taking and Interest Rates: Evidence from Decades in the
Global Syndicated Loan Market. International Finance
Discussion Papers 1188.
https://doi.org/10.17016/IFDP.2017.1188

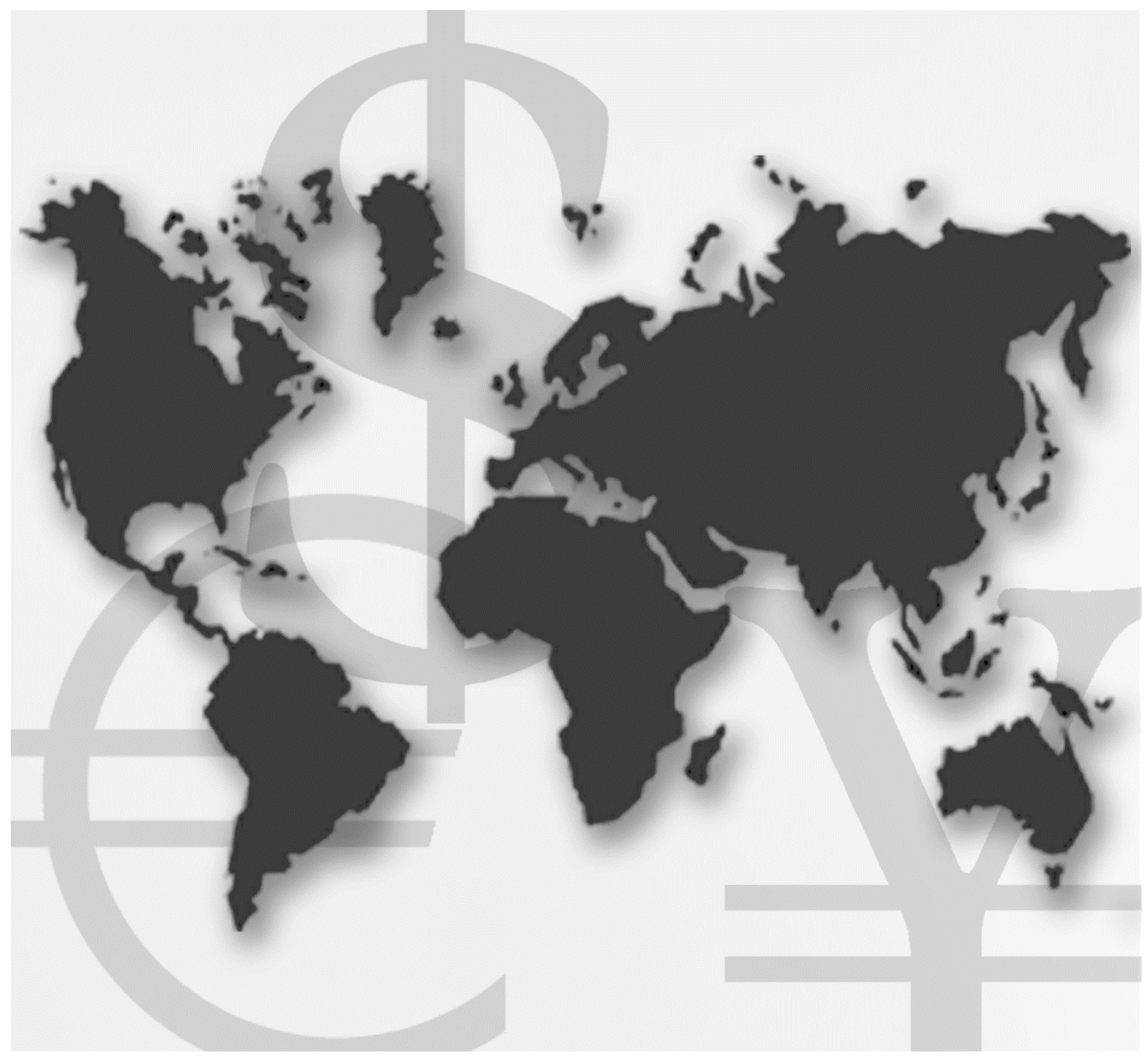

\section{International Finance Discussion Papers}

Board of Governors of the Federal Reserve System

Number 1188

January 2017 
Board of Governors of the Federal Reserve System

\title{
International Finance Discussion Papers
}

Number 1188

January 2017

Risk Taking and Interest Rates:

Evidence from Decades in the Global Syndicated Loan Market

\author{
Seung Jung Lee \\ Lucy Qian Liu \\ Viktors Stebunovs
}

NOTE: International Finance and Discussion Papers are preliminary materials circulated to stimulate discussion and critical comment. References in publications to International Finance Discussion Papers (other than an acknowledgment that the writer has had access to unpublished material) should be cleared with the author or authors. Recent IDFPs are available on the Web at www.federalreserve.gov/pubs/ifdp/. This paper can be downloaded without charge from Social Science Research Network electronic library at www. ssrn.com. 
Risk Taking and Interest Rates:

Evidence from Decades in the Global Syndicated Loan Market

\author{
Seung Jung Lee \\ Lucy Qian Liu ${ }^{\dagger}$ \\ Viktors Stebunovs $\ddagger$
}

Abstract: We study how low interest rates in the United States affect risk taking in the market for cross-border corporate loans. Because banks tend to originate these loans with intent to sell to nonbank investors, we examine risk taking by the broad financial system. To the extent that actions of the Federal Reserve affect U.S. interest rates, our analysis provides evidence of cross-border spillover effects of U.S. monetary policy and highlights the global lending and risk-taking channels. We find that movements in the U.S. interest rates have an important effect on ex-ante credit risk of cross-border corporate loans, though the channels are different in the pre- and post-crisis periods. Before the crisis, banks made ex-ante riskier loans to non-U.S. borrowers in response to a decline in U.S. short-term interest rates, and, after it, banks and nonbanks originated such loans in response to a decline in U.S. longerterm interest rates. Economic uncertainty, risk appetite, and the U.S. dollar exchange rate appear to play a limited role in explaining ex-ante credit risk. Our results highlight the potential policy challenges faced by central banks in affecting credit risk cycles in their own jurisdictions.

Keywords: Syndicated loans, risk taking, monetary policy, international spillovers.

JEL Classifications: E44, E52, F30, F42, G15, G20.

\# Board of Governors of the Federal Reserve System, 20th Street and Constitution Avenue, NW, Washington, DC 20551, U.S.A.; seung.j.lee@frb.gov. URL: http://www.federalreserve. gov/econresdata/seung-jung-lee.htm.

$\dagger$ International Monetary Fund, 700 19th Street, NW, Washington, DC 20431, U.S.A.; qliu3@imf.org.

$\ddagger$ Board of Governors of the Federal Reserve System, 20th Street and Constitution Avenue, NW, Washington, DC 20551, U.S.A.; viktors.stebunovs@frb.gov. URL: http://www. federalreserve.gov/econresdata/viktors-stebunovs.htm.

The views in this paper are solely the responsibility of the authors and should not be interpreted as reflecting the views of the Board of Governors of the Federal Reserve System, the International Monetary Fund, its Executive Board, or International Monetary Fund management or of any other person associated with these institutions. 


\section{Introduction}

In the aftermath of the global financial crisis, low interest rates maintained by central banks in advanced economies have sparked an intense debate on cross-border spillover effects of monetary policy. The literature highlights cross-border bank lending as a potential channel through which monetary conditions in one country affect capital flows and credit growth in the international financial system (Cetorelli and Goldberg (2011), Rey (2015), Bruno and Shin (2015), Obstfeld (2015)). Most studies in this literature focus on the direction and magnitude of cross-border flows; little has been done to study the riskiness of these flows. And, arguably, credit risk of flows - not just their direction or magnitude - matters a lot for financial stability. Indeed, some recent studies - for example, Kalemli-Ozcan, Sorensen, and Yesiltas (2012) - argue that quantitative measures of risky assets may not be sufficient to detect financial vulnerability as risk taking in the financial sector involves quality rather than the quantity of assets 1

Using market-based measures of credit risk, this paper examines how changes in U.S. interest rates and other factors affect risk taking by financial institutions in the global syndicated term loan market - a very large market for cross-border corporate loans. More specifically, we study whether low interest rates in the United States encourage lenders around the globe to supply riskier credit to non-U.S. borrowers, including borrowers in emerging market economies (EMEs), and whether this effect is more prominent for banks or nonbanks. In addition, we distinguish differential responses of risk taking to changes in U.S. short- and long-term interest rates. To the extent that actions of the Federal Reserve affect these interest rates, we provide evidence of cross-border spillover effects of U.S. monetary policy that are associated with the global lending channel.

The theoretical literature mostly focuses on the relationship between short-term policy interest rates and risk taking by depository institutions. In these models, the presence of asymmetric information and limited liability leads to a risk-shifting effect when interest rate rises, with an increase in deposit rate exacerbating agency problem and encouraging bank risk taking (see for example, Dell'Ariccia, Laeven, and Marquez (2014), Acharya and Viswanathan (2011)). In contrast, the portfolio allocation theory-far more general and applicable to a variety of types of financial intermediaries - predicts that a fall in interest rate on safe assets induces investors to shift away from safer assets towards riskier ones, thereby raising the riskiness of their portfolio. Furthermore, for financial institutions with fixed rate obligations, such as life insurance companies and pension funds, the choice of risk taking may reflect a "search for yield" incentive which induces them to take on more risk

\footnotetext{
$\sqrt[1]{\text { Kalemli-Ozcan, Sorensen, and Yesiltas }}(2012)$ present stylized facts on bank and firm leverage during the period 2000-09 using internationally comparable micro level data from many countries. Their results suggest that excessive risk taking before the crisis was not easily detectable because the risk involved the quality rather than the quantity of assets.
} 
as interest rates fall (Rajan (2005)). Thus, the overall effect of interest rates on risk taking may depend on the nature of interest rates - short-term versus long-term - and the type of financial intermediaries in consideration-banks versus nonbanks.

The global syndicated term loan market is a suitable venue to study this topic for several reasons. First, this market is comparable in size to the global corporate bond market and provides trillions of U.S. dollars a year to mostly nonfinancial corporations. Second, the vast majority of syndicated term loans are made to speculative-grade and obscure, nonrated corporations, so lenders take on very large positions in risky, mostly leveraged assets. Third, a significant portion of non-U.S. borrowers in the market is from EMEs, which allows us to identify more robustly the cross-border spillover effects. Fourth, while banks tend to originate the majority of syndicated term loans, they sell these loans very quickly to nonbank lenders, appearing to accommodate nonbanks' investment choices (Aramonte, Lee, and Stebunovs (2015)). Hence, the riskiness of these loans often reflects risk taking behavior by the broad financial system rather than just banks.

We focus on an ex-ante measure of credit risk proxied by loan spreads that are fixed at loan origination for the duration of a loan. These ex-ante measures of risk taking are market-based and have a couple of advantages over alternative measures. First, given that a typical loan has a maturity of several years, the loan spread captures the loan's credit risk smoothed (averaged) through the credit cycle. In other words, because loan spreads compensate for credit risk over the multi-year duration of loans, they look through the credit cycle, and, therefore, alleviate concerns about (contemporaneous) endogeneity of interest rates and credit risk. Second, in contrast to loan ratings which are widely used in the literature, loan spreads are not subject to ratings migration - a common phenomenon when an ex ante risky loan is initially given a higher rating which subsequently gets revised down over the loan's duration. To illustrate that loan spreads are a reliable proxy for ex-ante credit risk, for a subsample of loans, we provide evidence that loan spreads are strongly correlated with through-the-cycle probabilities of borrower default over a one-year horizon (a Basel II-consistent risk parameter) reported by lenders.

Empirical studies on the link between interest rate and risk taking are often subject to two major identification challenges. First, interest rates are endogenous to economic conditions, so an estimated relationship between interest rates and ex-ante credit risk may reflect some latent factors that drive simultaneous movements in the two variables. Second, changes in credit risk of a loan may reflect responses to both demand and supply factors, and disentangling one from another is difficult.

We adopt the following strategies to address these identification concerns. First, our main focus is cross-border spillover effects of U.S. monetary policy and other factors, so we restrict our sample to loans that are originated to non-U.S. borrowers - in some subsamples by nonU.S. lenders. This setup allows us to separate interest rate and credit cycles, and alleviate 
further concerns about endogeneity of U.S. interest rates and credit risk. In our work, as in Jimenez, Ongena, Peydro, and Saurina (2014) and Ioannidou, Ongena, and Peydro (2015), monetary conditions in one country are considered to be exogenous to developments in another country. Second, we conduct our main analysis at a loan level, and introduce controls for both credit supply (push) factors and credit demand (pull) factors. More specifically, we use lender country- and lender type-year effects to control for credit supply cycles specific to each lender, and borrower-type year and borrower-region year fixed effects to control for credit demand cycles specific to each borrower industry and region. In addition, we include controls for economic uncertainty and risk appetite that may affect willingness to lend.

We find robust evidence that lower U.S. interest rates encourage lenders of various types and nationalities to extend riskier loans to non-U.S. borrowers in the global syndicated loan market. Risk-taking behavior though responds differently to U.S. interest rate changes before and after the crisis. In the pre-crisis period, all else held equal, a decline in U.S. short-term interest rates encouraged lenders of various nationalities to originate riskier loans to nonU.S. borrowers. Once this effect is accounted for, movements in U.S. long-term interest rates did not have a statistically significant effect on risk taking. Given that the Federal Reserve explicitly targeted the federal funds rate during this period, our results present evidence of a risk-taking channel of U.S. monetary policy in the context of the global lending channel $L^{2}$ In contrast, for the post-crisis period, our results suggest that lenders of various types and nationalities originated riskier loans to non-U.S. borrowers in response to a decline in U.S. long-term interest rates. As the Federal Reserve de facto targeted U.S. longer-term interest rates during this period, our results again are consistent with a risk-taking channel of U.S. monetary policy ${ }^{3}$ The response of risk taking to the long-end of the U.S. yield curve may reflect the return-on-safer-assets and search-for-yield motives discussed in the theoretical literature.

Because investors tend to make risk management decisions based on credit risk of overall loan portfolios, not just individual loans, we also estimate risk-taking responses to U.S. interest rates and other factors at a lender portfolio level. The results from these sets of regressions reinforce what we find from the loan level regressions. In addition, we study how changes in U.S. interest rates affect risk taking by banks and nonbanks. We find that while banks took more credit risk in response to a decline in both U.S. short-term interest rates before the crisis and U.S. long-term rates after the crisis, nonbanks increased risk taking only when U.S. long-term rates decreased in the post-crisis period.

We acknowledge that one cannot contribute all the movement in interest rates to Federal

\footnotetext{
${ }^{2}$ The Federal Reserve was very successful in achieving the target, with the spread between the effective federal rate and its target averaged just a couple of basis points with a low variance.

${ }^{3}$ Recent research by Krishnamurthy and Vissing-Jorgensen (2011), D'Amico, English, López-Salido, and Nelson (2012), and D'Amico and King (2013), suggests that the Federal Reserve's unconventional monetary policy actions have reduced U.S. longer-term interest rates on safer assets. Of note, these post-crisis results are implicitly conditional on the zero lower bound for U.S. short-term rates.
} 
Reserve's actions in the post crisis period. For instance, following the European sovereign crisis, increased uncertainty and safe haven inflows to safer U.S. assets put additional downward pressures on U.S. longer-term interest rates. To control for such factors, we include a euro-area sovereign spread and Baker, Bloom, and Davis (2015)'s economic uncertainty index in the regressions. In addition, we include U.S. dollar exchange rate indexes as movement in the value of the U.S. dollar may affected the ability of non-U.S. borrowers to service U.S. dollar-denominated loans. However, these factors play only a limited role in explaining ex-ante credit risk of the syndicated loans.

Our paper contributes to the literature on the risk-taking channel of monetary policy and credit risk of capital flows. First, we examine cross-border spillover effects of U.S. monetary policy in terms of cross-border flows' quality rather than in terms of their quantity. We find evidence of risk-taking spillovers when low interest rates in one country encourage lenders to originate riskier loans to borrowers in other countries. Such spillovers highlight the potential challenges that central banks face, in particular those of EMEs, in affecting credit cycles in their respective jurisdictions. Second, we highlight different transmission channels of U.S. monetary policy before and after the crisis. While before the crisis changes in U.S. shortterm interest rates encouraged lenders to originate riskier cross-border loans, after the crisis changes in U.S. longer-term interest rates gave an incentive to lenders to originate such loans. Third, our analysis covers a broader financial system, which includes both banks and nonbanks, and further highlights different transmission channels of U.S. monetary policy before and after the crisis. We show that U.S. monetary policy affected risk taking by banks before the crisis and after it by both banks and nonbanks. Understanding nonbanks' risktaking behavior is important given the rapid expansion of shadow banking over the recent decades in general and over the post-crisis period in particular.

The reminder of the paper is organized as follows. Section 2 presents a brief literature review. Section 3 describes data sources, outlines key features of syndicated loans, and demonstrates that loan spreads are reasonable proxies for ex-ante credit risk metrics. Section 4 presents the empirical methodology that we use to examine the relationship between U.S. interest rates and ex-ante credit risk in the global syndicated term loan market. Section 5 summarizes the empirical results and discusses a number of robustness tests. Section 6 concludes with a few remarks on the implications of our findings for financial stability issues.

\section{Literature review}

Our paper contributes to several strands of the literature, including those on capital flows and the global lending channel, as well as the risk-taking channel of monetary policy.

The literature on capital flows and international bank lending mostly focuses on the direction and magnitude of cross-border financial flows. Using aggregate banking statistics 
data, Bruno and Shin (2015) study the effects of monetary policy spillovers on cross-border capital flows. Their results suggest that an expansionary shock to U.S. monetary policy leads to a increase in cross-border bank capital flows and an increase in the leverage of international banks. Similarly, Rey (2015) investigates the determinants of the global financial cycle using aggregate capital flow data, and finds that a decline in the federal fund rate leads to an increase in EU bank leverage (measured as the ratio of assets and liabilities) and an expansion of global credit flows. Furthermore, Temesvary, Ongena, and Owen (2015) examine the global bank lending channel using U.S. bank-level data. Their analysis shows that in response to changes in U.S. monetary conditions - both conventional and unconventional-U.S. banks adjust their cross-border claims. In contrast, our paper studies cross-border monetary policy spillovers using a rich loan-level data set, which enables us to properly control for different push and pull factors. More importantly, we focus on the quality instead of the quantity of credit flows, and provide direct evidence of the global risk- taking channel of U.S. monetary policy.

Our paper also complements the literature on the risk-taking channel of monetary policy, which has been growing in recent years, in part, because of prevalence of low interest rates around the world. Most empirical studies focus on banks as credit risk takers and on shortterm rates, typically associated with banks' funding costs, as the main driver. For instance, Dell'Ariccia, Laeven, and Suarez (2016) study how monetary policy affects risk taking in the U.S. banking system. Using confidential data on banks' internal ratings on small loans to businesses, they find that ex-ante risk taking by banks is negatively associate with shortterm interest rates and this negative relationship is more pronounced for highly capitalized banks. Because U.S. monetary policy is endogenous to U.S. credit and business cycles, their paper focuses on new business loans only which they argue are less likely to inform FOMC decisions.

Some papers explore the international dimension of risk-taking of monetary policy and use it as an strategy to strengthen identification. The findings in Jimenez, Ongena, Peydro, and Saurina (2014) show that banks in Spain take more credit risk as euro-area shortterm interest rates decline. In particular, such declines induce worse capitalized banks, on the extensive margin, to grant more loan applications to ex-ante risky firms and, on the intensive margin, to commit larger loan volumes with fewer collateral requirements to these firms. Ioannidou, Ongena, and Peydro (2015) provide evidence that banks in Bolivia grant riskier loans as U.S. short-term interest rates decline. Specifically, a decrease in the federal funds rate prior to loan origination raises the monthly probability of default on individual bank loans but banks do not seem to price this additional risk adequately. In both papers, monetary policy is exogenous to the host country of banks in consideration (Spain is in the euro area, where the European Central Bank determines a monetary policy stance, and Bolivia is a small, dollarized economy, with negligible importance for U.S. monetary policy). 
We follow a similar identification method by examining the relationship between U.S. interest rates and ex-ante credit risk of loans extended to non-U.S. borrowers. However, our data of cross-border loans covers lenders and borrowers from a wide range of countries, including EMEs, which allows us to look at risk taking in the global market. Moreover, we examine risk taking by both banks and nonbanks, and differentiate the effects of movements in U.S. short- and long-term interest rates.

Our paper is related to Aramonte, Lee, and Stebunovs (2015) who consider U.S. spot and forward longer-term interest rates and U.S. forward short-term interest rates as a main driver for ex-ante credit risk taking by various types of financial intermediaries. They use U.S. syndicated loan data over the zero-lower bound period to show that, in response to declines in U.S. spot and forward interest rates, nonbanks, such as investment funds, structured investment vehicles, and other shadow bank entities, acquired riskier term loans and banks facilitated these acquisitions $4^{4}$ Their results also indicate that nonbank lenders tend to acquire much riskier loan portfolios of term loans than banks do 5 To address potential endogeneity of credit risk and interest rates, they exploit the panel structure of their data and also rely on a sample of loans made to non-U.S. borrowers. Other papers that provide evidence on nonbanks' risk taking following monetary accommodation include ChodorowReich (2014) and Maggio and Kacperczyk (2016), but they both focus on the U.S. markets for short-term financial instruments only.

In contrast, our main focus is on the global lending channel and the cross-border spillovers of U.S. monetary policy and other factors. To that end, we use a commercial data set with extensive coverage of cross-border loans - term loans made by U.S. and non-U.S. lenders to U.S. and non-U.S. borrowers in the global syndicated market-over nearly two decades. The majority of borrowers are leveraged and borrow substantial amounts in the market. Because of the richness of our data, we can differentiate lenders and borrowers by their type, nationality, and credit ratings. In addition, the longer series of the data allows us to compare risk-taking channels of U.S. monetary policy before and after the crisis.

\section{Loan syndication: Data and features}

Before we describe the data, we provide some pointers on loan syndication and the global syndicated loan market. A syndicated loan is different from a simple bank loan or a corporate bond. It is extended to a borrower by multiple lenders which form a syndicate for that purpose, and it is administered by an agent, typically a bank. The loan's interest rate is

\footnotetext{
${ }^{4}$ They also examine risk taking in response to an increase in the expected extent and duration of the zero lower bound period.

5 Aramonte, Lee, and Stebunovs (2015) measure a loan's ex ante credit risk with a Basel II-consistent probability of default at a one-year horizon as reported by agent banks to their supervisors. Because banks report institutional-level ownership shares in loan syndications, they can construct acquisitions and holdings of syndicated loans by thousands of bank and nonbank lenders and assess their riskiness.
} 
floating; it is equal to a contractual loan spread over a benchmark interest rate. The spread is determined at origination, reflects lenders' judgments about the loan's credit risk, and stays constant over the loan's duration unless the loan's covenants are violated. For a given loan, its interest rate changes as the benchmark interest rate moves, therefore, minimizing lenders' interest rate risk.

Our data on syndicated loans are from Thomson Reuters Loan Pricing Corporation (LPC)'s DealScan, covering the period between 1995 and 2013. This data set contains detailed information on individual syndicated loans, borrowers' characteristics, and composition of the lending syndicates at loan origination. This richness helps with identification of cross-border spillovers of U.S. monetary policy and other factors.

In our analysis, we focus on term loans that are denominated in U.S. dollars, indexed to the U.S. dollar LIBOR, and originated in the global syndicated loan market. These loans are dispersed at origination, usually have a maturity of 5-7 years, and therefore, are more similar to corporate bonds than credit lines. We exclude credit lines from the analysis for two reasons. First, while a variety of different types of lenders acquire term loans, the lenders of credit lines are predominantly banks (see Aramonte, Lee, and Stebunovs (2015)). Second, because borrowers draw down credit lines at will, these lines have complex pricing than term loans and are more likely to be endogenous to the business and credit cycles ${ }^{6}$

In terms of market size, originations of syndicated term loans are comparable to issuance of nonfinancial corporate bonds, see panel (a) in Figure 1. Between the early 2000s and 2007, loan originations rose at a fast pace then subsequently collapsed during the crisis. Since reaching the trough in 2009, the syndicated loan markets had recovered substantially: ${ }^{7}$ Originations of term loans reached about $\$ 2$ trillion in 2013, of which roughly $\$ 700$ billion made to U.S. borrowers and $\$ 1.3$ trillion to non-U.S. borrowers. Syndicated lines of credit, extended mostly to borrowers in advanced economies, added another $\$ 2$ trillion to originations in the overall syndicated loan markets (not shown).

We analyze lending on an ultimate counterparty basis. Specifically, we aggregate lenders up to their parent organizations - to ultimate lenders. Similarly, we aggregate borrowers to their parent organizations - to ultimate borrowers. The approach reflects the notions that risk management in financial institutions is carried out at a parent-company level, and that borrower funding decisions are also made at a parent-company level. Another strong reason to perform analysis at an ultimate counterparty basis, is that parent organizations tend to guarantee debt being borrowed by their subsidiaries. In Appendix, we check for robustness of the results at an immediate counterparty basis.

For identification purposes, we distinguish lenders and borrowers by their types. We rely on two-digit SIC codes for primary activity given in the DealScan data to classify lenders.

\footnotetext{
${ }^{6}$ For pricing of credit lines' optionalities see Berg, Saunders, and Steffen $(2016)$.

${ }^{7}$ The syndicated loan market was unaffected by the spring 2013 turbulence, possibly because syndicated lenders do not generally bear interest rate risk.
} 
We consider two types of lenders: Banks and nonbanks, which include such shadow banking entities as finance companies, investment banks, investment funds, structured products, and insurance companies. As demonstrated later, these nonbank lenders have modest ownership shares at loan origination, thus economically it is more meaningful to group them together rather than analyze them separately 8 For borrowers, we rely on one-digit SIC codes to identify primary industries of borrowers. $9^{9}$

As noted above, one of the advantage of studying the global syndicated loan market is its wide coverage of lenders of various types and nationalities supplying credit to borrowers of varying credit quality from around the world. In terms of risk profile, the vast majority of syndicated term loans are extended to risky, opaque borrowers. As illustrated in Figure 1 panel (b), loans to nonrated borrowers dominated originations, whereas loans to investmentgrade and speculative-grade borrowers accounted for only modest to moderate fractions. Loan spreads on loans to nonrated borrowers are typically much higher than those on loans to investment-grade borrowers, but somewhat lower than those on loans to speculative-grade borrowers. In our data, risky loans - with contractual loan spread over 125-150 pointsaccount for the bulk of loan originations. Loans extended to nonrated and speculative-grade borrowers tend to be leveraged. In terms of geographical composition, loans extended to borrowers from EMEs accounted for a sizable share at origination. Panel (c) in Figure 1 and panel (c) in Figure 2 illustrate the volume composition and pricing of syndicated term loans extended to different groups of borrowers.

On the lenders side, nonbanks tend to originate riskier loans than banks do, as the contractual loan spreads for new loans made by nonbanks are significantly wider than the spreads for loans made by banks.10 In terms of market shares, banks and bank holding companies (BHCs) accounted for about 80 percent of originations volume globally, and the rest was originated by nonbank lenders, see panel (a) in Figure $3{ }^{11}$ The dominance of banks and BHCs at origination is partially driven by the fact that banks and BHCs have larger pools of potential borrowers and stronger capacity to evaluate the credit risk of borrowers than nonbanks have and do.

According to a separate date source - the confidential supervisory Shared National Credit (SNC) data, banks tend to originate syndicated loans with intent to distribute to lenders of other types that either pre-commit to buy shares in the loans being originated or buy those shares shortly after the origination directly from the originators or in the secondary market.

\footnotetext{
${ }^{8}$ We can perform the analysis by lender type at a finer level and show that the results hold for a broad set of nonbank lenders, but economic significance of these results may be lacking because of a small number of lenders in each of the finer lender types.

${ }^{9}$ In a limited number of cases when primary industry identifiers are missing for parent companies, we rely on primary industry identifiers of their subsidiaries.

${ }^{10}$ Consistently, as Aramonte, Lee, and Stebunovs (2015) find, the default probabilities of loans held by nonbank lenders (as identified in the SNC data) were also much higher than those held by banks.

${ }^{11}$ Moreover, among banks, originations were dominated by a group of select lenders.
} 
Indeed, banks' ownership shares in seasoned syndicated term loans tend to be much lower than those at origination. Indeed, in the U.S. market, banks and BHCs own only over a third of all term loans. Nonbanks such as investment funds, structured finance products, portfolio managers, finance companies, and other types account for the rest. From this perspective, nonbanks are well represented in the syndicated term loan market even though their share at origination does not appear to be large. To illustrate how fast banks sell their loan stakes to nonbanks, Figure 3 panel (b) plots the dynamics of banks' ownership share during the period after loan originations in the U.S. market. As shown in the picture, the median of banks' ownership shares of syndicated loans declines from about 80 percent to less than 20 percent in just a few weeks after the origination ${ }^{12}$

Before we describe our main regressions, we demonstrate that loan spreads in the primary syndicated loan market are reliable proxies for borrowers' ex ante credit risk, measured in terms of probabilities of borrower defaults. Several previous studies established the link between loan spreads and credit risk. For instance, Strahan (1999) argues that both the price and non-price terms of bank loans reflect observable components of borrower credit risk. Using Dealscan data, the paper shows that riskier borrowers - smaller borrowers, borrowers with less cash, and borrowers that are harder for outside investors to value - pay more for their loans. In addition, the non-price terms of loans are systematically related to pricing: Small loans, secured loans, and short-maturity loans carry higher interest rates than other loans, even after controlling for publicly available measures of risk. This suggests that banks use both the price and non-price terms of loans as complements in dealing with borrower risk 13

The theoretical underpinning of loan spreads as proxies for ex-ante probability default can be illustrated in a basic loan pricing model. For example, consider a risk-neutral perfectly competitive lender prices a loan which, for simplicity, has no guarantees or collateral. In this simple setup, perfect competition in the loan market and zero profit condition imply that the loan spread is proportional to the product of the probability of loan default and loss given default rate 14 In practice, however, syndicated term loans tend to have maturities of several years, many of these loans may have guarantees, collateral requirements, maintenance covenants, and some of them may be not senior, so the pricing of syndicated loans may be

\footnotetext{
${ }^{12}$ By retaining a small but economically significant share of syndicated loans, banks address the principleagent problem.

${ }^{13}$ Gaul and Stebunovs (2009) and many others present evidence that loan spreads also reflect private information about borrowers' risk characteristics. In addition, other market dynamics, market microstructure, overhead costs may contribute to the final determination of spreads. We will examine how such factors determine spreads later on in this section.

${ }^{14}$ The model can be also extended to include risk-averse lenders with pricing power and financing constraints of their own. In the more elaborated setup, other factors, such lenders' risk aversion, pricing power, and cost of funds (in excess of an increase in the U.S. dollar LIBOR, the benchmark rate used in pricing), could also determine loan spreads.
} 
more complicated than the model suggests 15

To test the empirical relationship between loan spreads and credit risk, we follow Aramonte, Lee, and Stebunovs (2015) and merge the commercial DealScan and quarterly SNC data together by loan terms (hard information). We then verify the matches using borrower names, which may be spelled differently in these two data sets (soft information). Because of the scope of the SNC data, our sample is restricted to the U.S. syndicated loan market, where both U.S. and non-U.S. lenders provide credit to U.S. borrowers and some non-U.S. borrowers. The sample covers the period from 2010 to 2013, as the quarterly data collection for the SNC program began only in 2009:Q4.

We measure ex-ante credit risk using a Basel II-consistent risk parameter - through-thecycle probability of borrower default at a one year horizon (PD). ${ }^{16}$ Figure 4 plots a simple correlation between loan spreads (all-in-drawn spreads) and probabilities of loan default, which shows that ex-ante riskier loans command higher loan spreads and that the relationship between the two is highly nonlinear (note that both PDs and loan spreads on the axes are logged) ${ }^{17}$ Table 1 reports some distribution statistics for the data presented in the figure. In line with our main data set of the long-series global syndicated term loans, the matched DealScan-SNC data sample is also dominated by term loans to non-rated borrowers. As noted above, these borrowers typically have probabilities of default much higher than those of investment-grade borrowers but somewhat lower than those of speculative-grade borrowers. ${ }^{18}$

To demonstrate formally the relationship between loan spreads and ex-ante credit risk, we estimate the following regression:

$$
\begin{aligned}
\log \left(\operatorname{spread}_{j, l, b, t}\right)=\alpha_{l}+\delta_{P D} \log \left(P D_{j, b, t}\right)+Q_{j, t} \delta_{Q} & \\
& +\beta_{T} R_{t}^{T}+X_{t} \gamma+\theta_{l, y}+\theta_{b, i, y}+\varepsilon_{j, l, b, t}
\end{aligned}
$$

where $\operatorname{spread}_{j, l, b, t}$ is the all-in-drawn spread for loan $j$ made/reported by lender $l$ to borrower

\footnotetext{
${ }^{15}$ Some loans could also get refinanced and the new loan may have a different spread. In addition, if the quality of the loan deteriorates over time, the spread may increase in a pre-determined fashion, as the syndicated loan contract may stipulate.

${ }^{16}$ The coverage of other risk parameters is rather limited in the SNC data, so we limit our analysis to probabilities of default. As in Aramonte, Lee, and Stebunovs (2015), we capture the ex-ante credit risk of each loan with the default probability that the reporting bank uses to determine regulatory capital. Regulations require banks to use through-the-cycle default probabilities that provide an assessment of a loan's credit risk at a one-year horizon.

${ }^{17}$ The all-in-drawn spread include annual fees, prorated based on loan maturity. In our sample, only a very small portion of loans have annual fees. Note that term loans are consistently drawn in full at origination. They have fewer built-in optionalities than credit lines and, hence, have fewer types of fees. As Berg, Saunders, and Steffen (2016) point out, the upfront fee is by far the most frequent of term loan fees, occurring nearly 30 percent of the time.

${ }^{18}$ As Aramonte, Lee, and Stebunovs (2015) point out, ratings appear to play a significant role in pricing of loans. (Ratings are based on Moody's senior debt ratings at the moment of origination as reported in DealScan.) Borrowers with outstanding debt rated as investment grade generally pay significantly lower loan spreads than borrowers with either not rated or speculative grade debt.
} 
$b$ at time $t ; P D_{j, b, t}$ is the probability of default of borrower $b$ that received loan $j ; Q_{j, t}$ is the vector of loan $j$ 's characteristics such as loan maturity and purpose; $R_{t}^{T}$ is the 10-year U.S. Treasury (zero-coupon) interest rate; $X_{t}$ is the vector of controls for risk appetite and macroeconomic factors; $\theta_{l, y}$ and $\theta_{b, i, y}$ are reporting bank $l$-year fixed effect and borrower industry-year fixed effects respectively. These fixed effects control for lender-specific and borrower industry-specific factors that change at an annual frequency. The regression also includes lender $j$ 's fixed effect $\alpha_{l}$ but not borrower $b$ 's fixed effect because we have too few repeated borrowers in the sample. $\varepsilon_{j, l, b, t}$ is a white noise error. We cluster errors by time because multiple loans originated in a given period are subject to the same macroeconomic and regulatory environment 19

The estimation results are reported in Table 2. As shown in column (1), PDs appear to play an important role in pricing syndicated loans. There is a positive, statistically significant relationship between $\log (\mathrm{spread}) \mathrm{s}$ and $\log (\mathrm{PD}) \mathrm{s}$; PDs explain about 40 percent of variation in loan spreads. In column (2), we add loan characteristics which increase the explanatory power by 10 percentage points. That is, inclusion of loan characteristics, which may be correlated with probabilities of default, improves the goodness of fit by several percentage points but does not materially affected the explanatory power of probabilities of default.

In column (3), we add various macroeconomic and financial factors that can potentially affect spreads - for example, risk aversion (a VIX-derived variance risk premium and spreads of U.S. low-grade corporate bonds over the U.S. Treasury rate) - and reporting bank-year fixed effects to account for agent characteristics that change gradually-for example, its capital and liquidity positions 20 Adding these variables improves the adjusted R-squared by only 6 percentage points, mostly due to reporting bank-year fixed effects, as regression coefficients on variance risk premium and other risk appetite variables are statistically insignificant. These results suggest that $\log (\mathrm{PD}) \mathrm{s}$ explain a significant portion of variation in $\log ($ spread $) s$, but financial and risk-aversion variables do not contribute much. In other words, loan spreads reflect mostly loan risk characteristics rather than variation in degrees of lenders risk aversion. In column (4), we add borrower industry-year fixed effects to account for borrower industry characteristics - for example, demand for bank loans - that change gradually. These additional fixed effects again improve the adjusted R-squared only marginally.

We rely on Aramonte, Lee, and Stebunovs (2015)'s findings to establish a causal link

\footnotetext{
${ }^{19}$ As shown in Petersen $(2009)$, in the presence of a time effect, standard errors clustered by time produce unbiased standard errors and correctly sized confidence intervals. The results are robust to clustering errors by either reporting bank or borrower industry.

${ }^{20} \mathrm{VRP}$ is calculated from options prices as the difference between the expected realized variance and the squared VIX index, considered to be the most readily available proxy for fluctuations in investors' risk aversion. Low-grade corporate bond spreads are from Merrill Lynch, which include corporate bonds of all maturities and all industries and are available from the early 1980s. Because low-grade bond is very risky (riskier than high-yield bonds), yields on these bonds are a good gauge of investor appetite for risky assets.
} 
between higher PDs of syndicated term loans that lenders either originate or buy and U.S. interest rates. They find that insurance companies, pension funds, and, in particular, structured-finance vehicles take higher credit risk in the U.S. domestic syndicated term loan market when financial markets expect interest rates to remain low. Banks originate riskier loans that they tend to divest shortly after origination, thus appearing to accommodate other lenders' investment choices. These results are consistent with a search for yield by certain types of shadow banks and, to the extent that Federal Reserve policies affected longer-term rates, the results are also consistent with the presence of a risk-taking channel of monetary policy.

To sum up, the empirical results above suggest that loan spreads are a reliable proxy for ex-ante credit risk and risk aversion plays only a minor role in pricing syndicated term loans. Loan spreads appear to be more comprehensive measures of ex-ante credit risk than PDs alone, as they also reflect other risk characteristics of loans ${ }^{21}$

Our main right-hand-side variables are U.S. interest rates. We use the effective federal funds rate as a measure of U.S. short-term interest rates which is highly correlated with funding costs and the 10-year U.S. Treasury (zero-coupon) rate as a measure of U.S. longterm interest rate which is highly correlated with returns on fixed income securities of various credit ratings. The former is the Federal Reserve's key monetary policy target in the precrisis period, while the latter is an implicit target in the post-crisis period after the federal funds rate reached the zero lower bound. Panel (a) in Figure 2 plots the time series of the two interest rates over our sample period. In the pre-crisis period, both U.S. short- and longer-term interest rates varied in a wide range. The two rates moved closely in the second half of 1990s, but subsequently diverged until 2006. The downward trend in 10-year U.S. Treasury rate over this period was possibly driven by better-anchored inflation expectations and the savings glut - two factors not related to the credit cycle. In the post-crisis period, though short-term interest rates stayed near zero, the 10-year U.S. Treasury rates declined initially but rebounded moderately in 2012-13.

\section{Empirical methodology}

We use the panel structure of the data to help with identification of risk taking in response to U.S. interest rates. Under this structure, each lender takes U.S. short- and longterm interest rates as given and makes their risk-taking decisions in response to changes in

\footnotetext{
${ }^{21}$ Because loan spreads reflect PDs and other risk characteristics, there may be a concern that our approximation of loss rates with loan spreads introduces a measurement error to our left-hand side variable in our benchmark model below. As Hausman (2001) points out, this may not be an issue. In regressions where the right-hand side variable is measured without error, the consequences of a mismeasured left-hand side variable are innocuous. In this case, the ordinary least squares estimator would be unbiased under a wide range of assumptions, but with reduced precision in the estimate, a lower t-statistic, and a reduced R-squared.
} 
U.S. dollar-denominated cost of funds and returns on safe assets. The identification is the strongest when we restrict our panel data to the sample of non-U.S. lenders extending loans to non-U.S. borrowers, as changes in U.S. interest rates are likely to be exogenous to changes in ex-ante credit risk in non-U.S. jurisdictions. In addition, the panel structure allows us to introduce various fixed effects to control for unobserved factors that may affect lenders and borrowers, which helps further strengthen identification.

Note that changes in U.S. interest rates may not only cause lenders to switch between borrowers with different risks and hence different loan spreads, they may also cause changes in the loan spreads themselves, for given levels of credit risk. Hence, our measure of credit risk is subject to a problem not present with other risk proxies, such as default-probability measures. To address this possibility, in regression model (1), we included controls for risk aversion, which appear to add little power in explaining loan spreads in addition to probabilities of default. In any case, in subsequent regressions, we include spreads of lowgrade corporate bonds over the U.S. Treasury rate to control for changes in risk aversion and we anticipate these effects of premiums related to risk aversion to be small.

We devise separate models to capture the relationship between U.S. interest rates and other factors and risk taking at a syndicate level and at a lender portfolio level. We can introduce more controls for so-called unobserved push and pull factors into the first type of regressions than into the second type of regressions but at a cost of a potential reduction in realism: Lenders may care more about credit risk of portfolios that they originate than about credit risk of one loan in those portfolios. Therefore, for completeness, we estimate models at both levels.

\subsection{Syndicate regressions}

Because of the skewness of the distribution of the explained variable, the benchmark syndicate model takes a semi-log form:

$$
\begin{aligned}
\log \left(\operatorname{spread}_{j, l, b, t}\right)=\alpha_{l}+\alpha_{b}+\underbrace{\beta_{F} R_{t}^{F}+\beta_{T} R_{t}^{T}+X_{t} \gamma}_{\text {h.f. push factors }} \\
+\underbrace{\theta_{l, c, y}+\theta_{l, i, y}}_{\text {l.f. push factors }}+\underbrace{\theta_{b, c, y}+\theta_{b, i, y}}_{\text {l.f. pull factors }}+\phi_{j, t}+\varepsilon_{j, l, b, t}
\end{aligned}
$$

where $\operatorname{spread}_{j, l, b, t}$ is the all-in-drawn spread for loan (syndicate) $j$ made/reported by lender $l$ to borrower $b$ at time $t ; R_{t}^{F}$ is the federal funds rate; $R_{t}^{T}$ is the 10-year U.S. Treasury (zero-coupon) interest rate; $X_{t}$ is the vector of controls for risk appetite and macroeconomic factors.

The $X$ controls include the following variables. We use the Merrill Lynch low-grade corporate bond spread to measure risk aversion and credit risk compensation in the sec- 
ondary corporate bond market, and use the VIX-derived variance risk premium, the European sovereign crisis (a spread between Italian and German sovereign yields), economic uncertainty (the U.S.-news based uncertainty index of Baker, Bloom, and Davis (2015)) to gauge lender risk appetite ${ }^{22}$ In addition, we include expected inflation (Michigan consumer survey-based expected 12-month inflation) to capture the notion that it may be a real interest rate that ultimately determine lenders' risk taking 23 In addition, we include U.S. dollar exchange rate indexes as movement in the value of the U.S. dollar may affected the ability of non-U.S. borrowers to service U.S. dollar-denominated loans. For example, an appreciate of the U.S. dollar index against borrower currencies may increase the debt servicing burden of borrowers' U.S. dollar denominated loans in absence of U.S. dollar-denominated revenues and currency hedges. In general, there is very limited information on non-U.S. public corporations' revenue currencies and currency hedges. In particular, because our sample is dominated by obscure, private borrowers, having more refined controls for exchange rate risk and debt servicing burdens appears to be not feasible. ${ }^{24}$

$\theta_{l, c, y}$ and $\theta_{l, i, y}$ are lender l's country group-year and type-year fixed effects respectively. In some regressions, we assign lender countries to 3 groups - the United States, non-U.S. advanced economies, and EMEs) and in others to 2 groups (non-U.S. advanced economies and EMEs). Based on lenders' industries, we assign lenders to 3 types - banks, nonbank financial lenders, and nonfinancial lenders. These fixed effects controls for unobserved factors that affect lender behavior at an annual frequency, which could be interpreted as push factors for the supply of credit to borrowers in various industries and countries.

Similarly, $\theta_{b, c, y}$ and $\theta_{b, i, y}$ are borrower country group-year and industry-year fixed effects, respectively, which control for borrower country- and industry-specific factors that change at an annual frequency. In the regressions, we assign borrower countries to only 2 groups (non-U.S. advanced economies and EMEs) because we drop loans to U.S. borrowers from the sample to ensure exogeneity of credit risk to U.S. interest rates. We create borrower industry-year fixed effects that are based on borrower industry SIC codes at one digit level. ${ }^{25}$ These fixed effects capture low frequency pull factors for the demand for credit by borrowers in various industries and countries. The regression also includes lender l's fixed effect $\alpha_{l}$,

\footnotetext{
${ }^{22}$ While Baker, Bloom, and Davis (2015) uncertainty index is derived from U.S. news sources, it captures uncertainty about events in both the United States and abroad. They seek to capture uncertainty about economic policy decisions, their effects on the economy, and uncertainty induced by policy inaction. They base this index on search results from 10 leading U.S. newspapers that tend to cover domestic and international developments.

${ }^{23}$ We use the survey-based expected inflation because the TIPS-based inflation compensation is not available prior to early 2000 s.

${ }^{24}$ In our robustness checks, we considered loans made to borrowers in industries that likely have a natural hedge against U.S. dollar movements such as commodity-related industries. This approach leads to a significant reduction in the sample size, but does not materially change the picture.

${ }^{25}$ While we can define such fixed effects at a finer industry level, they may not be estimated consistently across years. In some years, we may have too few observations for borrowers of certain industries in a certain region.
} 
borrower $b$ 's fixed effect $\alpha_{b}$, and variables that capture syndicate characteristics $\phi_{j, t}$, such as the number of lenders in a syndicated ${ }^{26} \varepsilon_{j, l, b, t}$ is a white noise error. We cluster errors by time because multiple loans originated in a given period are subject to the same macroeconomic and regulatory environment.

Although loan data are available at a higher frequency, we estimate the model at a quarterly frequency so that, for many given lenders and borrower-industry-region groupings, loan originations reach economically significant volumes. In addition, as loan syndication takes some time (30-60 days) and the negotiation period for each loan within in a given quarter is not known, analysis at a quarterly frequency appears to be the most appropriate ${ }^{27}$

The interpretation of $\beta_{F}$ and $\beta_{T}$, the main coefficients of interest, is straightforward: $\beta_{\mathrm{s}}$ capture the sensitivity of risk taking to changes in U.S. interest rates. The hypothesis is that the sensitivity of risk taking to U.S. interest rates is negative, indicating lenders originate riskier loans in response to a decline in U.S. interest rates. Note that because the regression model takes a semi-log form, for a given loan $j$, the marginal effect are evaluated around a given level of loan spreads.

In the regression output that follows, we focus on two separate risk-taking channels of monetary policy: One that is associated with movements the federal funds rate and the other with the 10-year U.S. Treasury rate. An alternative specification is to regress $\log (\mathrm{spread})$ on a slope of the yield curve (defined as the spread of the 10-year rate over the federal funds rate) rather than its components, but we do not do so for two reasons. First, the inclusion of the slope is equivalent to imposing a constraint on the coefficients of its components: The coefficients are restricted to be of the same absolute magnitude but of opposite signs. We prefer the data to speak about such coefficient restrictions. Second, in the post-crisis period, because the federal funds rate is at the zero lower bound, the movement in the slope would be mostly driven by the 10-year Treasury rate.

We first estimate regression model 2 for the pre- and post-crisis period separately, given the structural break in the interest rate series. For the pre-crisis period, we include both U.S. short- and long-term interest rates to test whether the two risk-taking channels of monetary policy operate simultaneously. For the post-crisis period, because the federal funds rate was at the zero lower bound beginning 2008:Q4, the regression includes the U.S. Treasury rate only. In addition, we estimate an extended version of the regression model over the entire sample period, which includes both the federal funds rate $\left(R^{F}\right)$ and the U.S. Treasury rate

\footnotetext{
${ }^{26}$ For larger loans, the number of lenders tends to be higher. Nonbank financial lenders may prefer to invest into somewhat different terms loans than banks, therefore, controlling for nonbank participation may be necessary. See, for example, Aramonte, Lee, and Stebunovs (2015).

${ }^{27}$ Analyzing the data at a quarterly rather than monthly frequency also helps to minimize seasonality concerns (more originations tend to be done towards quarter ends).
} 
$\left(R^{T}\right)$, as well as the interactions of these interest rates with a post-crisis dummy (Post2008):

$$
\begin{aligned}
& \log \left(\operatorname{spread}_{j, b, l, t}\right)=\alpha_{l}+\alpha_{b}+\beta_{F} R_{t}^{F}+\beta_{T} R_{t}^{T}
\end{aligned}
$$

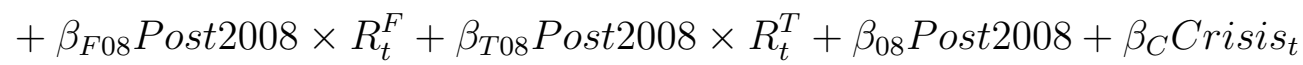

$$
\begin{aligned}
& +X_{t} \gamma+\theta_{l, c, y}+\theta_{l, i, y}+\theta_{b, c, y}+\theta_{b, i, y}+\phi_{j, t}+\varepsilon_{j, b l, t} .
\end{aligned}
$$

\subsection{Portfolio regressions}

The portfolio model captures the notion that lenders in general consider their risk-taking strategy at a loan portfolio level. While this may be a more realistic way to think about risk-taking decisions, we note that aggregation of loans into lenders' portfolios limits the number of unobserved pull factors that can be included in estimation.

We calculate the average loan spread of all term loans made by each lender in each quarter. For many loans in DealScan, the detailed share of ownership in a loan is not available. To overcome this issue, we can either construct simple averages of loan spreads for loans where a particular lender participated, or construct weighted averages of loan spreads based on the assumption used in the previous literature that lead lenders are assigned larger shares than other lenders. The results are not affected by the averaging method. Thus, we subsequently use simple-average loan spreads and refer to them as portfolio loan spreads. Similar to the syndicate regression, our benchmark portfolio model also takes a semi-log form:

$$
\begin{aligned}
\log \left(\text { pspread }_{b c, l, t}\right)=\alpha_{b c}+\alpha_{l}+\underbrace{\beta_{F} R_{t}^{F}+\beta_{T} R_{t}^{T}+\gamma X_{t}}_{\text {h.f. push factors }} & +\underbrace{\theta_{l, c, y}+\theta_{l, i, y}}_{\text {l.f. push factors }}+\underbrace{\theta_{b c, y}}_{\text {l.f. pull factors }}+\varepsilon_{l, b, t}
\end{aligned}
$$

where $\operatorname{spread}_{b c, l, t}$ is the average spread for loans originated by lender $l$ to borrowers in country group $b c$ at time t. $\alpha_{b c}$ is the borrower country group fixed effect. $\theta_{b c, y}$ is borrower country group-year fixed effect which represents a low frequency pull factor ${ }^{28}$ The other variables are the same as in regression model (2).

To make the results comparable with the syndicate regressions, we first estimate the portfolio model for the pre-and post-crisis periods separately. We then re-estimate the model for the entire sample period with post-crisis interaction terms in a similar fashion as that in

\footnotetext{
${ }^{28}$ As an alternative, we also use higher-frequency pull factor, such as average real GDP growth of borrower countries weighted by loan originations. The results are stronger as the alternative specification may have missed a variety of latent pull factors.
} 
the syndicate regressions (3):

$$
\begin{aligned}
& \log \left(\operatorname{pspread}_{b c, l, t}\right)=\alpha_{b c}+\alpha_{l}+\beta_{F} R_{t}^{F}+\beta_{T} R_{t}^{T}
\end{aligned}
$$

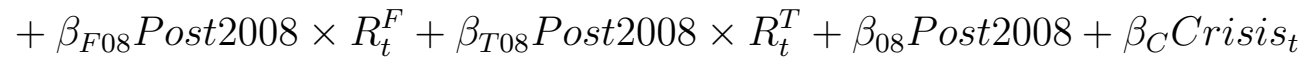

$$
\begin{aligned}
& +\gamma X_{t}+\theta_{l, c, y}+\theta_{l, i, y}+\theta_{b c, y}+\varepsilon_{l, b, t}
\end{aligned}
$$

where the notation is the same as in the earlier models.

Finally, we estimate a version of regression models 4 and 5 with separate regression coefficients on U.S. interest rates for banks and nonbanks. This regression model examines whether risk taking by bank and nonbanks responds differently to changes in U.S. interest rates. However, we note that these estimations may not provide a complete picture of risktaking strategies by different types of financial institutions. As stated above, although banks dominate loan originations, they quickly sell these loans to investors of other types who may pre-commit before origination to the purchase. Hence, the estimated coefficients $\beta_{F}$ and $\beta_{T}$ for banks may reflect risk taking by nonbanks at least to some extent.

Table 3 reports summary statistics for our main explained and explanatory variables. Since our regression analysis focus on non-U.S. borrowers, we report the loan spreads only for this group and EME borrowers. Interestingly, the average loan spread for EME borrowers at 1.67 percentage points is somewhat lower than that for non-U.S. borrowers more broadly (1.86 percentage points), which includes borrowers from both non-U.S. advanced economies and EMEs. The standard deviation for EME is also smaller. This may partially reflect the fact that mostly large firms with decent credit from EMEs borrow in the global syndicated loan market. The average federal fund rate is 3.0 percent with a standard deviation of 2.3 percent. In contrast, the 10-year Treasury rate displays a much smaller variation over the sample period, with a standard deviation of 1.4 percent.

\section{$5 \quad$ Estimation results}

This section presents our main findings about the effects of changes in U.S. interest rates on risk taking in the global syndicated loan market. In particular, we differentiate the roles played by U.S. short- and long-term interest rates in the pre- and post-crisis periods, as well as risk-taking responses by banks and nonbanks. We also present several robustness checks to enrich our main findings and to demonstrate that our main results are not driven by certain assumptions used in the analysis. It should be understood that the results for the post-crisis period are implicitly conditional on short-term rates being low, therefore, the cost-of-funds channel may be implicitly operational. In most of the regressions, we assume that lender risk management is carried out at a parent-company level and borrower funding decisions are taken at a parent-company level. 


\subsection{Syndicate regressions}

Loans made to non-U.S. borrowers by lenders of type and nationality. We first estimate models (2) and (3) over the sample of all non-U.S. borrowers and lenders on an ultimate counterparty basis. This is the broadest data cut that we can do while separating U.S. monetary cycle and non-U.S. credit cycles. The estimation results are reported in Table 4. Column (1) shows the results of regression model (2) for the pre-crisis period, and column (2) for the post-crisis period. In the latter specification, again the federal funds rate is excluded, because it was at the lower zero bound and its effect cannot be reliably estimated. In the pre-crisis period, the results point to a significantly negative relationship between U.S. short-term interest rates and ex ante risk taking, while the effects of movements in U.S. longterm rates is statistically insignificant. In contrast, the post-crisis period is characterized by a statistically significant negative relationship between U.S. long-term interest rates and risk taking. Column (3) shows the results for regression model (3) over the entire sample period which spans nearly two decades, including the global financial crisis episode. The result for the federal fund rate in the pre-crisis period remains similar, but the coefficient for the U.S. long-term rate is no longer statistically significant. This is due to the inclusion of the crisis quarters in this estimation ${ }^{29}$

Based on the regression estimates in columns (1) and (2), we can calculate the marginal effects in the neighborhood of average spreads ${ }^{30}$ The calculations suggest that, in the precrisis period, a one-standard deviation decrease in the federal funds rate of 1.82 percentage point leads to an increase in loan spreads by 11 basis points. In comparison, in the post-crisis period, a one-standard deviation decrease in the 10-year Treasury rate of 0.71 percentage point raises loan spreads by 28 basis points. Hence, the economic effect of U.S. long-term interest rates on risk taking in the post-crisis period appears to be much stronger than that of U.S. short-term interest rates in the pre-crisis period ${ }^{31}$

The estimated coefficients for the other explanatory variables are of interest too. While the coefficient on the variance risk premium is statistically insignificant across the specifications, the negative coefficient on the uncertainty index is statistically significant in the pre-crisis period, indicating that elevated uncertainty moderated lenders' appetite for riskier loans ${ }^{32}$ The coefficient on low-grade bond spreads is positive and consistently statistically

\footnotetext{
${ }^{29}$ Later, we show that on a portfolio basis, the effects of U.S. long-term rates on risk taking is present in both the post-crisis period and in the longer period that includes the crisis.

${ }^{30}$ The average spread during the pre-crisis period is about 100 basis points and the average in the post-crisis period is about 260 basis points.

${ }^{31}$ The changes in loan spreads can then be further mapped into changes in loan PDs based on the estimation results of regression model 1 1 . The caveat is that the mapping of PDs to loan spreads is based on U.S. data which mostly cover U.S. borrowers.

${ }^{32}$ The result that uncertainty index can outperform the VIX and VIX-derived indexes is consistent with the findings in other studies. For example, Baker, Bloom, and Davis (2015) examines the effects of uncertainty on firm-level investment and employment using both the VIX and the uncertainty index. They show that only the latter has negative and statistically significant effects.
} 
significant, which implies that a compression of loan spreads could be associated with broad improvements in investors' appetite for term loans. The coefficient on the European sovereign yield spread is only negative in column (2), likely because this period captures the European sovereign debt crisis and the risk off environment associated with it. The results for the U.S. dollar exchange rate index are not consistently statistically significant across the sample periods. While in the pre-crisis period the coefficient on the exchange rate is positive but not statistically significant, in the post-crisis period it is both positive and significant. The latter finding suggests that a U.S. dollar appreciation is associated with an increase in ex ante credit risk of loans being originated - consistently, with a higher debt servicing cost leading to a higher probability of default.

Loans made to non-U.S. borrowers by U.S. lenders. Next we restrict our sample to loans made to non-U.S. firms by U.S. lenders only. This sample cut is in the spirit of the nascent global lending channel literature which explains the magnitude and direction of U.S. bank lending to international borrowers caused by changes in U.S. monetary policy. Table 5 summarizes our results. The regression results are very similar to those reported in Table 4. where we find evidence of different risk-taking channels of monetary policy in the preand post-crisis periods. Notably, for the U.S. lender sample, the magnitude of the estimated coefficient for 10-year Treasury rate in the post-crisis period is much larger in absolute terms, which suggests that the economic effect of long-term rate changes on risk taking is somewhat stronger for U.S. lenders than for non-U.S. lenders. Overall, even restricting the sample to U.S. lender-non-U.S. borrower loans, we find evidence that low U.S. interest rates induce risk taking in the global syndicated term loan market.

Loans made to EME borrowers by non-U.S. lenders. In the final exercise at a syndicate level, we restrict the sample to loans made to borrowers in EMEs by non-U.S. lenders. In terms of exogeneity, this is the strongest specification that we have, as the credit and business cycles in EMEs are less likely to co-move with U.S. interest rates comparing to the cycles in non-U.S. advanced economies. In addition, it is also the strongest specification to demonstrate the cross-border spillover effects of U.S. monetary policy through the global lending channel. Table 6 summarizes our results. Again, most results are very close to those presented in Table 4. This suggests that the earlier results are not driven solely by the interactions of U.S. lenders and borrowers from non-U.S. advanced economies. In sum, our main results are robust to restricting the sample to loans made by non-U.S. lenders to EME borrowers. 


\subsection{Portfolio regressions}

We now summarize the regression results of the portfolio models. This setup is more consistent with the idea that the lenders make decisions on risk management and risk taking based on their portfolios of loans. To strengthen identification, we study two types of portfolios by lender: One comprised of loans made to borrowers in non-U.S. advanced economies and the other of loans made to EME borrowers. This allows us to introduce borrower country group-year fixed effects that control for credit demand and other unobserved factors.

Loans made to non-U.S. borrowers by lenders of any type and nationality. Table 7 reports the estimation results for this subsample. Similar to the results in Tables 4 and 6 , we find that the federal funds rate has a negative and statistically significant effect on ex-ante risk taking in the pre-crisis period, whereas the 10-year Treasury rate has a negative and statistically significant effect in the post-crisis period. Unlike the results in the syndicated loan regressions, however, the coefficient for the interaction term of 10-year Treasury rate and the post-crisis dummy is negative and statistically significant in the full sample specification. That is, our full-sample portfolio model confirms the differential effects of U.S. short- and long-term interest rates on ex-ante risk taking in the pre- and post-crisis periods. Indeed, the difference in magnitude between the two channels is amplified based on the larger differences between the estimated coefficients on the federal funds rate and the 10-year Treasury rate. These results reinforce the findings that are based on syndicated loan level regressions and provide greater economic significance. Some other differences to be noted are that, in the portfolio level regressions, the European sovereign spread and low-grade bond spread are statistically significant only in column (3) of the full sample specification. The results for the U.S. dollar exchange rate index are not statistically significant across the sample periods.

Loans made to non-U.S. borrowers by lenders of two types - banks and nonbanksand of any nationality Finally, we test the hypothesis whether risk taking by banks and nonbanks responds differently to changes in U.S. interest rates. Table 8 reports the results. The estimation indicates that banks originate riskier loans in response to declines in the federal funds rate before the crisis and in the 10-year Treasury rate after the crisis. In contrast, nonbanks only load on risk in response to declines in the 10-year Treasury rate in the post-crisis period. These findings to some extent are in line with the implications from the portfolio theory literature in the sense that risk taking by banks is likely driven by both cost-of-fund and return-on-safer-asset concerns, whereas risk taking by nonbanks are likely motivated by return-on-safer asset or search-for-yield incentives. The different responses in risk taking by bank and nonbanks are particularly interesting given the gradual increase in the share of nonbank participants in the global syndicated term loan market. As such, the growing nonbank participation may present different policy implications in addressing the 
financial stability concern related to risk taking.

\subsection{Robustness checks and caveats}

In the appendix, we offer a few robustness checks. First, we note that while lenders and borrowers' risk management decisions are generally made at a parent level, some decisions to lend or borrow may be made on a local or immediate basis. Hence, we reestimate regression models (2) to (5) based on an immediate counterparty basis. The results on an immediate basis are weaker but still consistent with those on an ultimate counterparty basis. Second, we estimate our models using two additional subsamples - loans extended to nonrated and speculative borrowers (that is, excluding investment-grade borrowers) and loans originated by the most active lenders (lenders that lend in the market in every quarter). We find that omitting loans to investment-grade borrowers and restricting the sample to loans from made by the most active lenders give statistically stronger results. In a way, we offer a falsification test where the cost-of-funds and returns-on-safer-assets channels associated with lower interest rates do not generally apply to loans made to investment-grade borrowers.

We acknowledge that our work has a couple of caveats. First, we do not observe lenders' entire portfolios, which may include a variety of other financial instruments, not just syndicated loans. For example, lenders may hedge exposures to the syndicated term loan market in other financial markets. In this case, additional risk taking in the syndicated loan market as a result of low U.S. interest rates may not necessarily represent a general increase in the riskiness of a given lender's assets. Second, the strength of our results on the risk-taking channel that operates through U.S. long-term interest rates in the post-crisis period may partly reflect expansionary monetary policies in other large advanced economies, not just in the United States. However, the combinations of fixed effects that we use alleviate such concerns.

Finally, we acknowledge that our work has some caveats. For example, we do not observe lenders' entire portfolios, which may include a variety of instruments. Lenders may hedge exposures to the syndicated term loan market in other financial markets. In this case, additional risk taking in the syndicated loan market as a result of low interest rates may not necessarily represent a general increase in the riskiness of the financial sector.

\section{Conclusions}

This paper provides evidence on the negative relationship between U.S. interest rates and ex-ante risk taking in the global syndicated term loan market. Our empirical analysis differentiates the risk-taking channels associated with U.S. short- and long-term interest rates before and after the global financial crisis. We find that, in the pre-crisis period, as U.S. short-term interest rates declined, all else held equal, lenders of various nationalities tended 
to originate riskier loans to both non-U.S. borrowers. In the post-crisis period, however, lenders of various types and nationalities tended to originate riskier loans in response to declines in U.S. long-term interest rates. The results are particularly strong for the sample of loans made by non-U.S. lenders to EME borrowers.

Our findings suggest the existence of cross-border spillovers of low interest rates in one country that encourage risk taking in other countries. Such spillovers highlight the potential challenges faced by central banks, particularly those in EMEs, in affecting risk taking in lending and, more broadly, credit cycles in their respective jurisdictions. For example, while a central bank is tightening to cool off the country's credit cycle, other foreign central banks may be loosening, and, hence, inadvertently encouraging internationally active lenders to extend credits to riskier borrowers in that country. To this end, central banks may have to rely on coordination of multiple policy tools, such as monetary and macro-prudential policies, to ensure both economic and financial stability (see Rey (2015) and Obstfeld (2015) for further policy discussions related to the global financial cycle).

Our analysis contributes to a recent policy debate on whether the prolonged low interest rate environment has increased vulnerabilities in the financial system. As noted above, our evidence on additional risk taking is limited to the global syndicated loan market and syndicated lenders may have hedged potential losses from syndicated loan defaults. Nevertheless, through the hedge, other financial intermediaries may have to compensate for these losses if defaults were to occur. Hence, in aggregate, the financial system could be strained as a result of additional risk taking. That being said, increases in risk taking in the aftermath of the crisis may have also aided economic recovery are they, in fact, may be consistent with goals of U.S. expansionary monetary policy.

In sum, an increase in risk taking by lenders is one of the channels by which accommodative monetary policy is intended to spur economic activity. At the same time, of course, greater risk taking may pose risks to financial stability domestically and globally. Assessing the trade-off between these effects is beyond the scope of this paper, but is clearly a high priority both at the Federal Reserve and at central banks around the world.

\section{References}

Acharya, V. V., And S. Viswanathan (2011): "Leverage, Moral Hazard, and Liquidity," Journal of Finance, 66(1), 99-138.

Aramonte, S., S. J. Lee, and V. Stebunovs (2015): "Risk Taking and Low Longerterm Interest Rates: Evidence from the U.S. Syndicated Loan Market," FEDS Working Paper 2015-068, Federal Reserve Board. 
Baker, S. R., N. Bloom, and S. J. Davis (2015): "Measuring economic policy uncertainty," mimeo, Stanford University.

Berg, T., A. Saunders, and S. Steffen (2016): "The Total Cost of Corporate Borrowing in the Loan Market: Don’t Ignore the Fees," Journal of Finance, 71(3), 1357-1392.

Bruno, V., And H. S. Shin (2015): "Capital flows and the risk-taking channel of monetary policy," Journal of Monetary Economics, 71, 119 - 132.

Cetorelli, N., And L. S. Goldberg (2011): "Global Banks and International Shock Transmission: Evidence from the Crisis," IMF Economic Review, 59(1), 41-76.

Chodorow-Reich, G. (2014): "Effects of Unconventional Monetary Policy on Financial Institutions," Brookings Papers on Economic Activity, 48(1 (Spring), 155-227.

D’Amico, S., W. English, D. López-Salido, and E. Nelson (2012): "The Federal Reserve's Large-scale Asset Purchase Programmes: Rationale and Effects," Economic Journal, 122(564), F415-F446.

D'Amico, S., And T. B. King (2013): "Flow and stock effects of large-scale treasury purchases: Evidence on the importance of local supply," Journal of Financial Economics, $108(2), 425-448$.

Dell'Ariccia, G., L. Laeven, and R. Marquez (2014): "Real interest rates, leverage, and bank risk-taking," Journal of Economic Theory, 149, 65-99.

Dell'Ariccia, G., L. Laeven, and G. Suarez (2016): "Bank Leverage and Monetary Policy's Risk-Taking Channel; Evidence from the United States," ECB Working Papers 13/143, European Central Bank.

Gaul, L., And V. Stebunovs (2009): "Ownership and Asymmetric Information Problems in the Corporate Loan Market: Evidence from a Heteroskedastic Regression," OCC Working paper 2009-1, Office of the Comptroller of the Currency.

Hausman, J. (2001): "Mismeasured variables in econometric analysis: Problems from the right and problems from the left," Journal of Economic Perspectives, 15(4), 57-67.

IoAnnidou, V., S. Ongena, And J. Peydro (2015): "Monetary policy, risk-taking and pricing: Evidence from a quasi-natural experiment," Review of Finance, 19(1), 95-144.

Jimenez, G., S. Ongena, J. Peydro, and J. SAurina (2014): "Hazardous times for monetary policy: What do twenty-three million bank loans say about the effects of monetary policy on credit-risk taking?," Econometrica, 82(2), 463-505.

Kalemli-Ozcan, S., B. Sorensen, and S. Yesiltas (2012): "Leverage across firms, banks, and countries," Journal of International Economics, 88(2), 284-298.

Krishnamurthy, A., And A. Vissing-Jorgensen (2011): "The Effects of Quantitative Easing on Interest Rates: Channels and Implications for Policy," Brookings Papers on Economic Activity, Fall, 215-265.

Maggio, M. D., And M. KacperczyK (2016): "The Unintended Consequences of the Zero Lower Bound Policy," Working Paper 22351, National Bureau of Economic Research. 
Obstfeld, M. (2015): "Trilemmas and trade-offs: living with financial globalisation," BIS Working Papers 480, Bank for International Settlements.

Petersen, M. A. (2009): "Estimating Standard Errors in Finance Panel Data Sets: Comparing Approaches," Review of Financial Studies, 22(1), 435-480.

Rajan, R. G. (2005): "Has Financial Development Made the World Riskier?," NBER Working Papers 11728, National Bureau of Economic Research, Inc.

Rey, H. (2015): "Dilemma not Trilemma: The global Financial Cycle and Monetary Policy Independence," Working Paper 21162, National Bureau of Economic Research.

Strahan, P. E. (1999): "Borrower Risk and the Price and Nonprice Terms of Bank Loans," FRBNY Staff Report 90, Federal Reserve Bank of New York.

Temesvary, J., S. Ongena, and A. L. Owen (2015): "Global Lending Channel Unplugged? Does U.S. Monetary Policy Affect Cross-border and Affiliate Lending by Global U.S. Banks?," CFS Working Paper 511, Center for Financial Studies. 

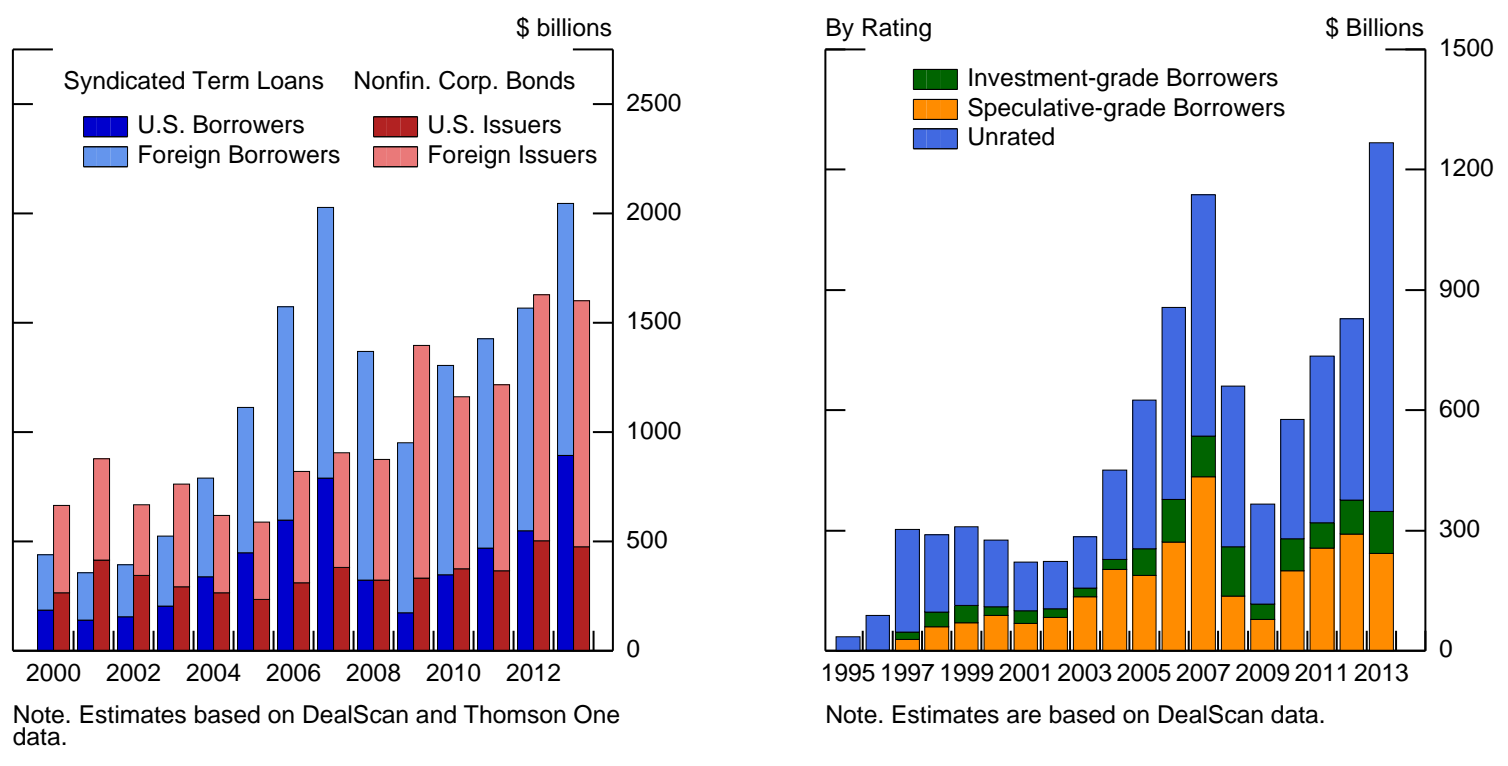

(a) Issuance of bonds and originations of loans (b) Originations of loans by borrower debt rating

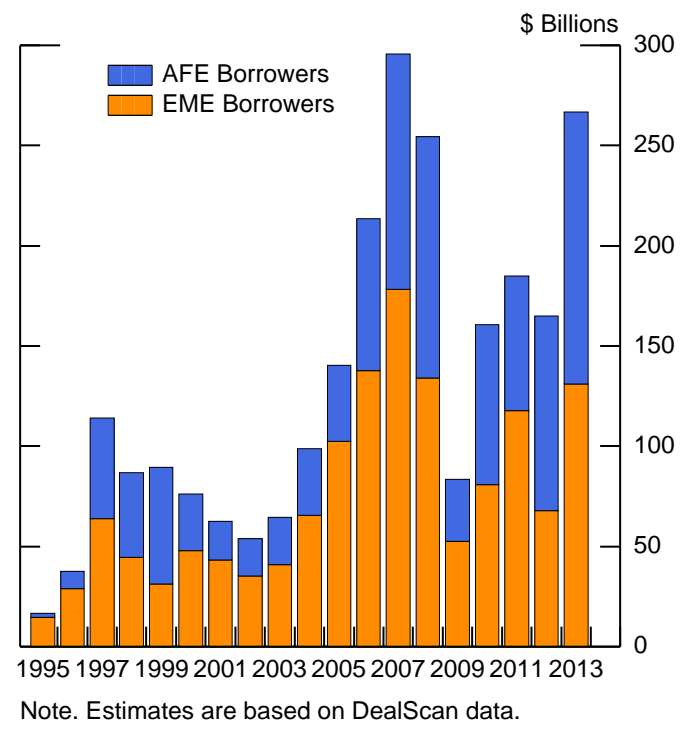

(c) Originations of loans by borrower country

\section{Figure 1: Issuance of corporate bonds and origination of syndicated term loans}

The figure is based on syndicated term loans that are denominated in U.S. dollars, indexed to the U.S. dollar LIBOR, and originated in the global market. In panel (a), originations of syndicated term loans are comparable in size to issuance of nonfinancial corporate bonds. In panel (b), the majority of syndicated term loans are made to speculative-grade and unrated debt borrowers; these loans tend to be leveraged. In panel (c), originations of syndicated term loans made to non-U.S. borrowers that are used to estimate regression models 2 to 5 . 


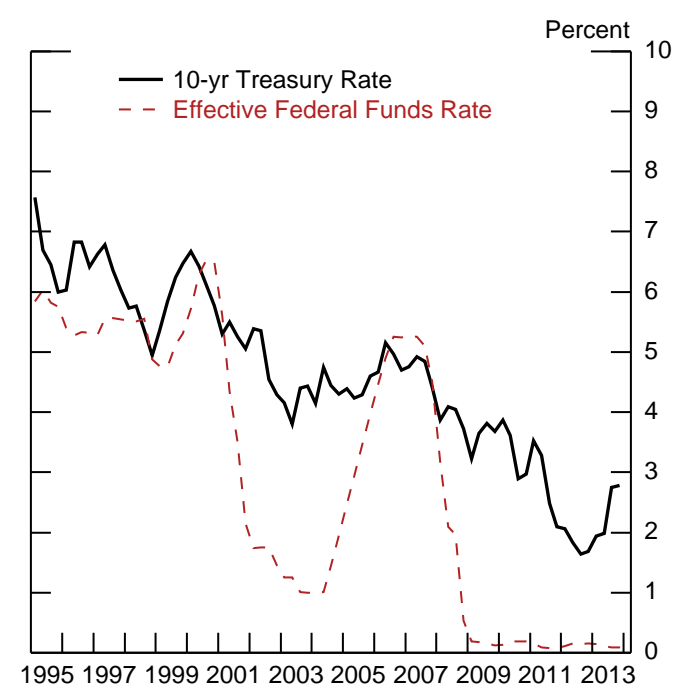

(a) U.S. interest rates

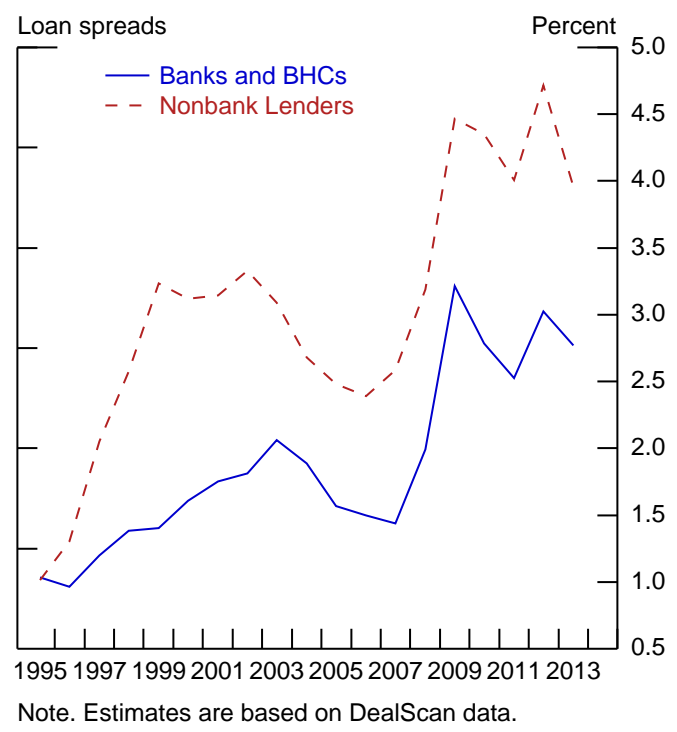

(b) Loan spreads by lender type

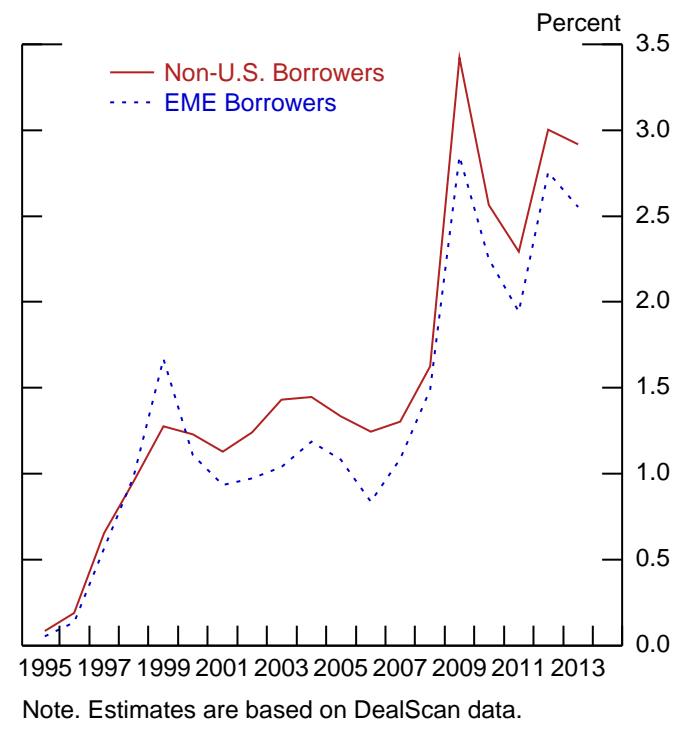

(c) Loan spreads by borrower country

\section{Figure 2: U.S. interest rates and pricing of syndicated term loans}

Panel (a) suggests breaking up the sample into pre- and post-crisis periods as the federal funds rate reached the zero lower bound in late 2008. Panels (b) and (c) are based on syndicated term loans that are denominated in U.S. dollars, indexed to the U.S. dollar LIBOR, and originated in the global market. Loan spreads are weighted by loan amounts. In panel (b), nonbank financial lenders tend to lend to borrowers of higher credit risk as suggested by higher loan spreads. In panel (c), loans made to EME borrowers tend to be somewhat less risky than loans made to AFE borrowers. 


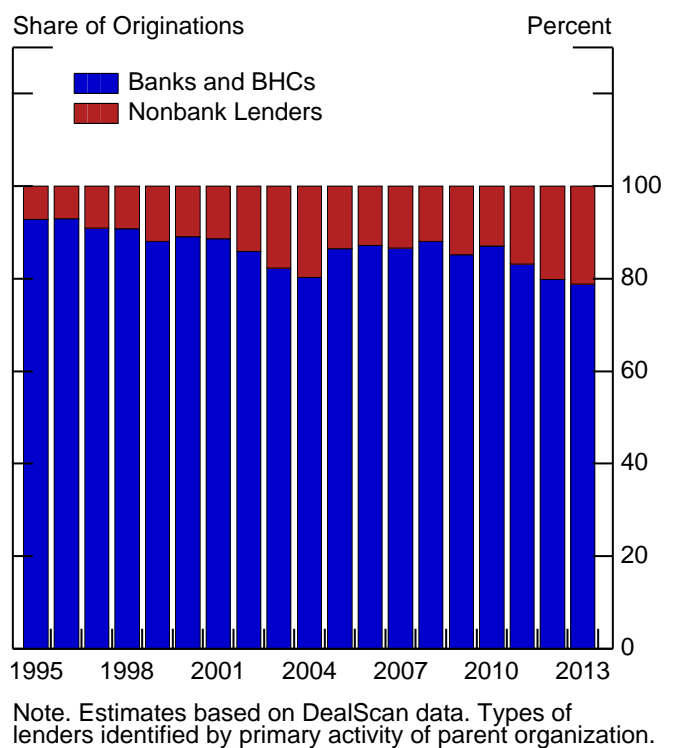

(a) Banks' ownership share of syndicated loans at origination

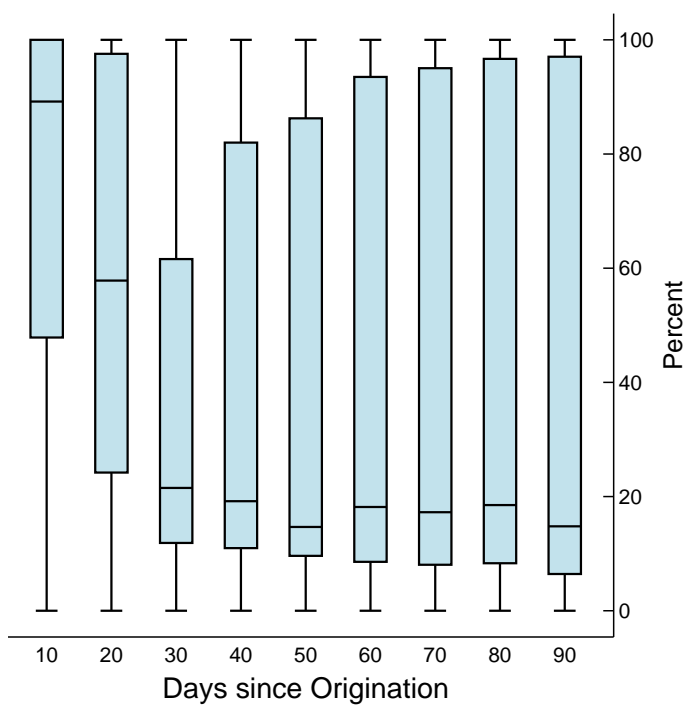

(b) Banks' ownership share of syndicated loans since origination

\section{Figure 3: Ownership of syndicated term loans at origination and over time}

Panel (a) is based on syndicated term loans that are denominated in U.S. dollars, indexed to the U.S. dollar LIBOR, and originated in the global market. It shows that banks now account for 80 percent of loan ownership at origination. Panel (b) is based on syndicated term loans made in the United States in the last several years. It shows a sequence of box plots for bank ownership shares at different time intervals since loan originations. The panel suggests that banks sell off their shares of loans to nonbank financial intermediaries - such shadow bank entities as funds and structured products - quickly. In fact, the median of bank shares in syndicated loans falls from 90 percent at origination to 20 percent within a month. Similar data for the global market are believed not to exist. 


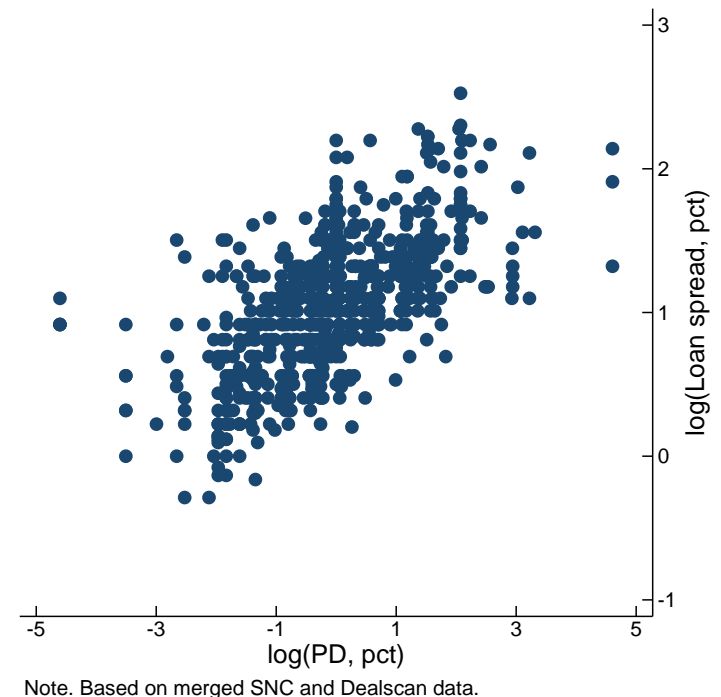

Figure 4: Loan spreads and probabilities of borrower default

The figure is based on syndicated term loans made in the United States in the last several years. It shows that loan spreads that are fixed at origination for the duration of loans are highly positively correlated with through-the-cycle probabilities of borrower default over a one year horizon.

Table 1: Descriptive statistics for loan pricing regressions

\begin{tabular}{lrrrrr}
\hline \hline Variable & Mean & Std.dev. & 10th p. & 50th p. & \multicolumn{1}{c}{90 thp. } \\
\hline Loan spread, pct & 3.101 & 1.633 & 1.500 & 2.750 & 5.000 \\
Probability of default, pct & 2.317 & 7.110 & 0.170 & 0.800 & 4.820 \\
10-year Treas. rate, pct & 2.346 & 0.581 & 1.710 & 2.050 & 3.200 \\
Variance risk premium, pct sq. & 14.439 & 6.218 & 7.365 & 14.034 & 25.099 \\
Sovereign yield spread, pct & 2.954 & 1.005 & 1.597 & 2.867 & 4.367 \\
Low-grade bond spread, pct & 4.855 & 0.884 & 3.622 & 4.840 & 5.839 \\
High-yield CDX, pct & 4.873 & 1.033 & 3.482 & 4.819 & 6.300 \\
Expected inflation, pct & 3.222 & 0.341 & 2.900 & 3.100 & 3.800 \\
\hline
\end{tabular}

Note. The sample includes loan originations with available probabilities of default in the Shared National Credit data that are matched with loan originations in the DealScan data. The sample period is 2010:Q1-2013:Q4 because of the limited availability of probabilities of default. Loan spread statistics based on over 700 term loans, denominated in U.S. dollars, index to the U.S. dollar LIBOR, and originated in the U.S. syndicated loan market. Other variables statistics based on 16 quarters of data. 
Table 2: Loan spreads as proxies for ex-ante credit risk

\begin{tabular}{|c|c|c|c|c|}
\hline & $\begin{array}{l}(1) \\
\mathrm{PD}\end{array}$ & $\begin{array}{c}(2) \\
\text { Loan char. }\end{array}$ & $\begin{array}{c}(3) \\
\text { Macro/Bank FE }\end{array}$ & $\begin{array}{c}(4) \\
\text { Bank FE/Borr. FE }\end{array}$ \\
\hline $\log (\mathrm{PD}, \mathrm{pct})$ & $\begin{array}{l}0.231^{* * *} \\
(10.773)\end{array}$ & $\begin{array}{c}0.206^{* * *} \\
(12.069)\end{array}$ & $\begin{array}{c}0.190^{* * *} \\
(10.489)\end{array}$ & $\begin{array}{c}0.189^{* * *} \\
(9.870)\end{array}$ \\
\hline $\log (\operatorname{loan}$ amount, $\$$ bill. $)$ & & $\begin{array}{l}-0.030^{* *} \\
(-2.411)\end{array}$ & $\begin{array}{l}-0.036^{* * *} \\
(-2.987)\end{array}$ & $\begin{array}{l}-0.040^{* * *} \\
(-3.551)\end{array}$ \\
\hline $\log ($ duration, years $)$ & & $\begin{array}{l}0.166^{* * *} \\
(5.819)\end{array}$ & $\begin{array}{l}0.128^{* * *} \\
(3.907)\end{array}$ & $\begin{array}{l}0.157^{* * *} \\
(4.116)\end{array}$ \\
\hline LBO or takeover loan purpose & & $\begin{array}{l}0.223^{* * *} \\
(3.721)\end{array}$ & $\begin{array}{l}0.151^{* *} \\
(2.496)\end{array}$ & $\begin{array}{l}0.152^{* *} \\
(2.430)\end{array}$ \\
\hline Nontraded loan & & $\begin{array}{l}-0.066 \\
(-1.668)\end{array}$ & $\begin{array}{l}-0.120^{* * *} \\
(-5.900)\end{array}$ & $\begin{array}{l}-0.122^{* * *} \\
(-5.638)\end{array}$ \\
\hline Public company & & $\begin{array}{l}-0.195^{* * *} \\
(-6.351)\end{array}$ & $\begin{array}{l}-0.178^{* * *} \\
(-6.301)\end{array}$ & $\begin{array}{l}-0.175^{* * *} \\
(-6.124)\end{array}$ \\
\hline Non-IG borrower rating & & $\begin{array}{l}0.194^{* * *} \\
(3.042)\end{array}$ & $\begin{array}{l}0.193^{* * *} \\
(3.106)\end{array}$ & $\begin{array}{l}0.179^{* *} \\
(2.841)\end{array}$ \\
\hline 10-year Treas. rate, pct & & & $\begin{array}{l}-0.072 \\
(-0.964)\end{array}$ & $\begin{array}{l}-0.093 \\
(-1.367)\end{array}$ \\
\hline VRP, pct sq. & & & $\begin{array}{c}0.005 \\
(1.197)\end{array}$ & $\begin{array}{c}0.004 \\
(1.225)\end{array}$ \\
\hline European sovereign spread, pct & & & $\begin{array}{c}0.000 \\
(0.010)\end{array}$ & $\begin{array}{l}-0.004 \\
(-0.159)\end{array}$ \\
\hline Low-grade bond spread, pct & & & $\begin{array}{c}0.025 \\
(0.196)\end{array}$ & $\begin{array}{l}-0.017 \\
(-0.139)\end{array}$ \\
\hline CDX high yield, pct & & & $\begin{array}{l}-0.088 \\
(-1.074)\end{array}$ & $\begin{array}{l}-0.052 \\
(-0.653)\end{array}$ \\
\hline Expected inflation, pct & & & $\begin{array}{c}0.004 \\
(0.073)\end{array}$ & $\begin{array}{l}-0.016 \\
(-0.283)\end{array}$ \\
\hline News-based uncertainty index & & & $\begin{array}{l}-0.001 \\
(-1.165)\end{array}$ & $\begin{array}{l}-0.001 \\
(-1.420)\end{array}$ \\
\hline Reporting bank-year fixed effects & No & $\mathrm{No}$ & Yes & Yes \\
\hline Borrower industry-year fixed effects & No & No & No & Yes \\
\hline Num. of observations & 709 & 709 & 709 & 709 \\
\hline R-sq. adj. & 0.40 & 0.50 & 0.56 & 0.57 \\
\hline RMSE & 0.37 & 0.34 & 0.32 & 0.31 \\
\hline
\end{tabular}

$t$ statistics in parentheses. ${ }^{*} p<.1,{ }^{* *} p<.05,{ }^{* * *} p<.01$.
Note. The output shown is for regression model 1 . Based on DealScan loans matched with the Shared National Program data, which primarily cover loans to U.S. borrowers in the U.S. market. Dependent variable is from DealScan and independent, loan-specific variables from the Shared National Program. Dependent variable is $\log$ (loan spread, pct) of loan $j$ reported by agent bank $l$ in quarter $t$. Inclusion of loan characteristics improves the goodness of fit but does not affected the explanatory power of $\log (\mathrm{PD}$, pct) where $\mathrm{PD}$ is the through-the-cycle probability of borrower default used by the reporting bank in calculation of risk weights. Reporting bank-year fixed effects capture bank-specific conditions, such as capital and liquidity pressures, that change at an annual frequency. Borrower industry-year fixed effects capture borrower industry-specific conditions, such as creditworthiness and demand for credit, that change at an annual frequency. Fixed effects are not shown. Errors clustered by quarters. 
Table 3: Descriptive statistics for loan portfolio spread regressions

\begin{tabular}{lrrrrr}
\hline \hline Variable & \multicolumn{1}{c}{ Mean } & Std.dev. & 10th $p$. & 50th p. & \multicolumn{1}{c}{90 th $p}$. \\
\hline Loan spread, pct & & & & & \\
$\quad$ Non-U.S. borrowers & 1.860 & 1.529 & 0.425 & 1.400 & 3.875 \\
EME borrowers & 1.667 & 1.352 & 0.425 & 1.250 & 3.500 \\
Fed. funds rate, pct & 3.010 & 2.336 & 0.119 & 3.056 & 5.723 \\
10-year Treas. rate, pct & 4.474 & 1.414 & 2.414 & 4.533 & 6.354 \\
Variance risk premium, pct sq. & 19.577 & 13.423 & 6.976 & 16.149 & 34.171 \\
Sovereign yield spread, pct & 1.290 & 1.552 & 0.183 & 0.385 & 4.163 \\
Expected inflation, pct & 2.977 & 0.535 & 2.435 & 2.967 & 3.504 \\
Low-grade bond spread, pct & 5.273 & 2.550 & 3.119 & 4.705 & 7.867 \\
News-based uncertainty index & 110.801 & 39.651 & 69.307 & 100.557 & 168.622 \\
\hline \hline
\end{tabular}

Note. The sample period is 1995:Q1-2013:Q4. Loan spreads are for syndicated term loans that are denominated in U.S. dollars, indexed to the U.S. dollar LIBOR, and originated in the global market. In the sample, there are 9980 loans to non-U.S. borrowers of which 7589 are loans to EME borrowers. U.S. news source-based uncertainty index captures uncertainty in the United States and abroad, see Baker, Bloom, and Davis (2015). 
Table 4: Syndicate regressions: Loans made by all lenders to non-U.S. borrowers

\begin{tabular}{|c|c|c|c|}
\hline & $\begin{array}{c}(1) \\
\text { Pre-crisis }\end{array}$ & $\begin{array}{c}(2) \\
\text { Post-crisis }\end{array}$ & $\begin{array}{l}(3) \\
\text { Full }\end{array}$ \\
\hline Fed. funds rate, pct & $\begin{array}{c}-0.062^{* *} \\
(-2.594)\end{array}$ & & $\begin{array}{l}-0.075^{* * *} \\
(-4.308)\end{array}$ \\
\hline 10-year Treas. rate, pct & $\begin{array}{c}0.037 \\
(0.870)\end{array}$ & $\begin{array}{l}-0.150^{* * *} \\
(-3.275)\end{array}$ & $\begin{array}{c}-0.010 \\
(-0.253)\end{array}$ \\
\hline Variance risk premium, pct sq. & $\begin{array}{c}0.002 \\
(1.636)\end{array}$ & $\begin{array}{c}-0.005 \\
(-1.491)\end{array}$ & $\begin{array}{c}0.000 \\
(0.253)\end{array}$ \\
\hline European sovereign spread, pct & $\begin{array}{c}0.014 \\
(0.395)\end{array}$ & $\begin{array}{l}-0.108^{* * *} \\
(-4.709)\end{array}$ & $\begin{array}{c}0.003 \\
(0.154)\end{array}$ \\
\hline Expected inflation, pct & $\begin{array}{c}-0.036 \\
(-1.022)\end{array}$ & $\begin{array}{l}0.241^{* * *} \\
(3.637)\end{array}$ & $\begin{array}{c}0.043^{*} \\
(1.707)\end{array}$ \\
\hline Low-grade bond spread, pct & $\begin{array}{c}0.099^{* *} \\
(2.168)\end{array}$ & $\begin{array}{l}0.127^{* * *} \\
(4.353)\end{array}$ & $\begin{array}{l}0.041^{* * *} \\
(3.187)\end{array}$ \\
\hline News-based uncertainty index & $\begin{array}{l}-0.003^{* * *} \\
(-3.497)\end{array}$ & $\begin{array}{c}-0.000 \\
(-0.803)\end{array}$ & $\begin{array}{l}-0.001^{* * *} \\
(-2.658)\end{array}$ \\
\hline U.S. dollar exch. rate (broad) & $\begin{array}{c}0.004 \\
(0.485)\end{array}$ & $\begin{array}{l}0.044^{* * *} \\
(3.236)\end{array}$ & $\begin{array}{l}0.009^{* *} \\
(2.422)\end{array}$ \\
\hline Post-2008 × 10-year Treas. rate, pct & & & $\begin{array}{c}-0.011 \\
(-0.199)\end{array}$ \\
\hline Post-2008 & & & $\begin{array}{l}0.498^{* *} \\
(2.193)\end{array}$ \\
\hline Dummy for crisis quarters & & & $\begin{array}{c}-0.091^{*} \\
(-1.794)\end{array}$ \\
\hline Syndicate composition controls & Yes & Yes & Yes \\
\hline Lender type-year fixed effects & Yes & Yes & Yes \\
\hline Lender country-year fixed effects & Yes & Yes & Yes \\
\hline Borrower industry-year fixed effects & Yes & Yes & Yes \\
\hline Borrower country-year fixed effects & Yes & Yes & Yes \\
\hline Num. of observ. & 61507 & 18687 & 89655 \\
\hline Num. of clusters & 50 & 18 & 76 \\
\hline R-sq. within & 0.34 & 0.31 & 0.42 \\
\hline RMSE & 0.31 & 0.18 & 0.32 \\
\hline \multicolumn{4}{|c|}{$\begin{array}{l}t \text { t statistics in parentheses. }{ }^{*} p<.1,{ }^{* *} p<.05,{ }^{* * *} p<.01 . \\
\text { Note. The output shown is for regression models } 2 \text { and } 3 \text { Based on } \\
\text { U.S. dollar-denominated, U.S. dollar LIBOR-indexed term loans made by } \\
\text { all lenders to non-U.S. borrowers on an ultimate counterparty basis in the } \\
\text { global market. Dependent variable is } \log (\operatorname{loan} \text { spread, pct) of loan } j \text { in quar- } \\
\text { ter } t \text { made to borrower } b \text { from country } b, c \text { in industry } b, i \text { by lender } l \text { of type } \\
l, i \text { from country } l, c \text {. Syndicate composition controls, including the number } \\
\text { of lenders in each loan, and fixed effects not shown. Column (3) includes } \\
\text { crisis quarters from 2007:Q3 to 2009:Q2. Errors clustered by quarters. }\end{array}$} \\
\hline
\end{tabular}


Table 5: Syndicate regressions: Loans made by U.S. lenders to non-U.S. borrowers

\begin{tabular}{|c|c|c|c|}
\hline & $\begin{array}{c}(1) \\
\text { Pre-crisis }\end{array}$ & $\begin{array}{c}(2) \\
\text { Post-crisis }\end{array}$ & $\begin{array}{l}\text { (3) } \\
\text { Full }\end{array}$ \\
\hline Fed. funds rate, pct & $\begin{array}{c}-0.065^{* *} \\
(-2.325)\end{array}$ & & $\begin{array}{c}-0.049^{* *} \\
(-2.357)\end{array}$ \\
\hline 10-year Treas. rate (z.c.), pct & $\begin{array}{c}0.073 \\
(1.010)\end{array}$ & $\begin{array}{l}-0.261^{* * *} \\
(-3.730)\end{array}$ & $\begin{array}{c}-0.013 \\
(-0.215)\end{array}$ \\
\hline Variance risk premium, pct sq. & $\begin{array}{c}0.002 \\
(0.796)\end{array}$ & $\begin{array}{c}0.004 \\
(0.806)\end{array}$ & $\begin{array}{c}-0.001 \\
(-0.443)\end{array}$ \\
\hline European sovereign spread, pct & $\begin{array}{c}0.030 \\
(0.415)\end{array}$ & $\begin{array}{l}-0.121^{* *} \\
(-2.384)\end{array}$ & $\begin{array}{c}0.007 \\
(0.195)\end{array}$ \\
\hline Expected inflation, pct & $\begin{array}{c}-0.061 \\
(-1.212)\end{array}$ & $\begin{array}{c}0.113 \\
(0.820)\end{array}$ & $\begin{array}{c}-0.008 \\
(-0.261)\end{array}$ \\
\hline Low-grade bond spread, pct & $\begin{array}{l}0.189^{* * *} \\
(3.050)\end{array}$ & $\begin{array}{c}0.061 \\
(1.637)\end{array}$ & $\begin{array}{l}0.070^{* * *} \\
(3.187)\end{array}$ \\
\hline News-based uncertainty index & $\begin{array}{l}-0.004^{* * *} \\
(-3.119)\end{array}$ & $\begin{array}{l}-0.002^{* *} \\
(-2.456)\end{array}$ & $\begin{array}{l}-0.001^{* *} \\
(-2.443)\end{array}$ \\
\hline U.S. dollar exch. rate (broad) & $\begin{array}{c}-0.015 \\
(-0.996)\end{array}$ & $\begin{array}{c}0.026 \\
(1.055)\end{array}$ & $\begin{array}{c}0.004 \\
(0.648)\end{array}$ \\
\hline Post-2008 × 10-year Treas. rate, pct & & & $\begin{array}{c}0.044 \\
(0.492)\end{array}$ \\
\hline Post-2008 & & & $\begin{array}{c}0.394 \\
(1.033)\end{array}$ \\
\hline Dummy for crisis quarters & & & $\begin{array}{l}-0.110 \\
(-1.184)\end{array}$ \\
\hline Syndicate composition controls & Yes & Yes & Yes \\
\hline Lender type-year fixed effects & Yes & Yes & Yes \\
\hline Lender country-year fixed effects & Yes & Yes & Yes \\
\hline Borrower industry-year fixed effects & Yes & Yes & Yes \\
\hline Borrower country-year fixed effects & Yes & Yes & Yes \\
\hline Num. of observ. & 6588 & 2130 & 9568 \\
\hline R-sq. w. & 0.40 & 0.41 & 0.45 \\
\hline RMSE & 0.31 & 0.17 & 0.31 \\
\hline RMSE & 0.30 & 0.18 & 0.32 \\
\hline
\end{tabular}

$t$ statistics in parentheses. ${ }^{*} p<.1,{ }^{* *} p<.05,{ }^{* * *} p<.01$.
Note. The output shown is for regression models 2 and 3 Based on U.S. dollar-denominated, U.S. dollar LIBOR-indexed term loans made by U.S. lenders to non-U.S. borrowers on an ultimate counterparty basis in the global market. Dependent variable is $\log$ (loan spread, pct) of loan $j$ in quarter $t$ made to borrower $b$ from country $b, c$ in industry $b, i$ by lender $l$ of type $l, i$ from country $l, c$. Syndicate composition controls, including the number of lenders in each loan, and fixed effects not shown. Column (3) includes crisis quarters from 2007:Q3 to 2009:Q2. Errors clustered by quarters. 
Table 6: Syndicate regressions: Loans made by non-U.S. lenders to EME borrowers

\begin{tabular}{|c|c|c|c|}
\hline & $\begin{array}{c}(1) \\
\text { Pre-crisis }\end{array}$ & $\begin{array}{c}(2) \\
\text { Post-crisis }\end{array}$ & $\begin{array}{l}(3) \\
\text { Full }\end{array}$ \\
\hline Fed. funds rate, pct & $\begin{array}{c}-0.068^{* *} \\
(-2.567)\end{array}$ & & $\begin{array}{l}-0.079^{* * *} \\
(-3.847)\end{array}$ \\
\hline 10-year Treas. rate, pct & $\begin{array}{c}0.047 \\
(1.017)\end{array}$ & $\begin{array}{l}-0.210^{* *} \\
(-2.588)\end{array}$ & $\begin{array}{c}-0.001 \\
(-0.034)\end{array}$ \\
\hline Variance risk premium, pct sq. & $\begin{array}{l}0.005^{\text {*** }} \\
(3.097)\end{array}$ & $\begin{array}{c}-0.004 \\
(-0.692)\end{array}$ & $\begin{array}{c}0.002 \\
(1.375)\end{array}$ \\
\hline European sovereign spread, pct & $\begin{array}{c}0.003 \\
(0.087)\end{array}$ & $\begin{array}{l}-0.129^{\text {*** }} \\
(-3.475)\end{array}$ & $\begin{array}{c}-0.024 \\
(-1.036)\end{array}$ \\
\hline Expected inflation, pct & $\begin{array}{c}-0.026 \\
(-0.574)\end{array}$ & $\begin{array}{l}0.201^{* * *} \\
(3.986)\end{array}$ & $\begin{array}{c}0.044 \\
(1.593)\end{array}$ \\
\hline Low-grade bond spread, pct & $\begin{array}{l}0.116^{* * *} \\
(4.039)\end{array}$ & $\begin{array}{l}0.129^{* * *} \\
(3.521)\end{array}$ & $\begin{array}{l}0.054^{* * *} \\
(3.984)\end{array}$ \\
\hline News-based uncertainty index & $\begin{array}{l}-0.004^{* * *} \\
(-4.174)\end{array}$ & $\begin{array}{c}-0.001^{*} \\
(-1.985)\end{array}$ & $\begin{array}{l}-0.001^{* *} \\
(-2.452)\end{array}$ \\
\hline U.S. dollar exch. rate (EME) & $\begin{array}{c}0.001 \\
(0.100)\end{array}$ & $\begin{array}{l}0.026^{* *} \\
(2.253)\end{array}$ & $\begin{array}{c}-0.001 \\
(-0.185)\end{array}$ \\
\hline Post-2008 × 10-year Treas. rate, pct & & & $\begin{array}{c}-0.050 \\
(-0.912)\end{array}$ \\
\hline Post-2008 & & & $\begin{array}{c}0.534^{* *} \\
(2.281)\end{array}$ \\
\hline Dummy for crisis quarters & & & $\begin{array}{l}-0.183^{* * *} \\
(-3.666)\end{array}$ \\
\hline Syndicate composition controls & Yes & Yes & Yes \\
\hline Lender type-year fixed effects & Yes & Yes & Yes \\
\hline Lender country-year fixed effects & Yes & Yes & Yes \\
\hline Borrower industry-year fixed effects & Yes & Yes & Yes \\
\hline Borrower country-year fixed effects & Yes & Yes & Yes \\
\hline Num. of observ. & 45472 & 13736 & 66109 \\
\hline Num. of clusters & 50 & 18 & 76 \\
\hline R-sq. w. & 0.36 & 0.35 & 0.44 \\
\hline RMSE & 0.30 & 0.18 & 0.32 \\
\hline
\end{tabular}

$t$ statistics in parentheses. ${ }^{*} p<.1,{ }^{* *} p<.05,{ }^{* * *} p<.01$.
Note. The output shown is for regression models 2 and 3 Based on U.S. dollar-denominated, U.S. dollar LIBOR-indexed term loans originated in the global market to EME borrowers on an ultimate counterparty basis. Dependent variable is $\log$ (loan spread, pct) of loan $j$ in quarter $t$ made to borrower $b$ from country $b, c$ in industry $b, i$ by lender $l$ of type $l, i$ from country $l, c$. Syndicate composition controls, including the number of lenders in each loan, and fixed effects not shown. Column (3) includes crisis quarters from 2007:Q3 to 2009:Q2. Errors clustered by quarters. 
Table 7: Portfolio regressions: Portfolios of loans made by all lenders to non-U.S. borrowers

\begin{tabular}{|c|c|c|c|}
\hline & $\begin{array}{c}(1) \\
\text { Pre-crisis }\end{array}$ & $\begin{array}{c}(2) \\
\text { Post-crisis }\end{array}$ & $\begin{array}{c}(3) \\
\text { Full }\end{array}$ \\
\hline Fed. funds rate, pct & $\begin{array}{c}-0.028^{*} \\
(-1.970)\end{array}$ & & $\begin{array}{l}-0.036^{* * *} \\
(-3.419)\end{array}$ \\
\hline 10-year Treas. rate, pct & $\begin{array}{c}0.040^{*} \\
(1.690)\end{array}$ & $\begin{array}{l}-0.219^{* *} \\
(-2.560)\end{array}$ & $\begin{array}{c}0.036 \\
(1.555)\end{array}$ \\
\hline Variance risk premium, pct sq. & $\begin{array}{c}0.002 \\
(1.590)\end{array}$ & $\begin{array}{c}0.002 \\
(0.623)\end{array}$ & $\begin{array}{c}0.002^{*} \\
(1.975)\end{array}$ \\
\hline European sovereign spread, pct & $\begin{array}{c}-0.015 \\
(-0.637)\end{array}$ & $\begin{array}{c}-0.049 \\
(-0.963)\end{array}$ & $\begin{array}{l}-0.037^{* *} \\
(-2.292)\end{array}$ \\
\hline Expected inflation, pct & $\begin{array}{c}0.005 \\
(0.195)\end{array}$ & $\begin{array}{c}0.088 \\
(0.842)\end{array}$ & $\begin{array}{c}0.021 \\
(0.889)\end{array}$ \\
\hline Low-grade bond spread, pct & $\begin{array}{c}0.019 \\
(0.611)\end{array}$ & $\begin{array}{c}0.032 \\
(1.329)\end{array}$ & $\begin{array}{l}0.037^{* * *} \\
(3.799)\end{array}$ \\
\hline News-based uncertainty index & $\begin{array}{l}-0.002^{* *} \\
(-2.487)\end{array}$ & $\begin{array}{l}-0.002^{* *} \\
(-2.892)\end{array}$ & $\begin{array}{l}-0.002^{* * *} \\
(-4.346)\end{array}$ \\
\hline U.S. dollar exch. rate (broad) & $\begin{array}{c}0.002 \\
(0.361)\end{array}$ & $\begin{array}{c}0.016 \\
(1.138)\end{array}$ & $\begin{array}{c}-0.004 \\
(-1.331)\end{array}$ \\
\hline Post-2008 × 10-year Treas. rate, pct & & & $\begin{array}{l}-0.214^{* * *} \\
(-5.227)\end{array}$ \\
\hline Post-2008 & & & $\begin{array}{l}1.327^{* * *} \\
(8.806)\end{array}$ \\
\hline Dummy for crisis quarters & & & $\begin{array}{c}-0.012 \\
(-0.168)\end{array}$ \\
\hline Lender type-year fixed effect & Yes & Yes & Yes \\
\hline Lender country-year fixed effect & Yes & Yes & Yes \\
\hline Borrower country-year fixed effect & Yes & Yes & Yes \\
\hline Num. of observ. & 14675 & 4791 & 21591 \\
\hline Num. of lenders & 1690 & 675 & 1974 \\
\hline Num. of clusters & 50 & 18 & 76 \\
\hline R-sq. within & 0.15 & 0.12 & 0.32 \\
\hline RMSE & 0.49 & 0.38 & 0.48 \\
\hline
\end{tabular}

$t$ statistics in parentheses. ${ }^{*} p<.1,{ }^{* *} p<.05,{ }^{* * *} p<.01$.

Note. The output shown is for regression models 4 and 5 . Based on U.S. dollar-denominated, U.S. dollar LIBOR-indexed term loans originated in the global market to non-U.S. borrowers on an ultimate counterparty basis. Dependent variable is $\log$ (average spread of loan portfolio, pct) of lender $l$ from country $l, c$ of type $l, i$ made to borrowers from country $b, c$ in quarter $t$. Fixed effects not shown. Column (3) includes crisis quarters from 2007:Q3 to 2009:Q2. Errors clustered by quarters. 
Table 8: Portfolio regressions: Portfolios of loans made by bank and nonbank financial lenders to non-U.S. borrowers

\begin{tabular}{|c|c|c|c|}
\hline & $\begin{array}{c}(1) \\
\text { Pre-crisis }\end{array}$ & $\begin{array}{c}(2) \\
\text { Post-crisis }\end{array}$ & $\begin{array}{c}(3) \\
\text { Full }\end{array}$ \\
\hline Bank $\times$ Fed. funds rate, pct & $\begin{array}{c}-0.029^{* *} \\
(-2.135)\end{array}$ & & $\begin{array}{l}{ }^{-0.036^{* * *}} \\
(-3.705)\end{array}$ \\
\hline Nonbank $\times$ Fed. funds rate, pct & $\begin{array}{c}0.000 \\
(0.009)\end{array}$ & & $\begin{array}{c}-0.016 \\
(-0.461)\end{array}$ \\
\hline Bank $\times 10$-year Treas. rate, pct & $\begin{array}{c}0.044^{*} \\
(1.906)\end{array}$ & $\begin{array}{l}-0.224^{* *} \\
(-2.565)\end{array}$ & $\begin{array}{c}0.040^{*} \\
(1.790)\end{array}$ \\
\hline Nonbank $\times 10$-year Treas. rate, pct & $\begin{array}{c}0.008 \\
(0.168)\end{array}$ & $\begin{array}{c}-0.207^{* *} \\
(-2.116)\end{array}$ & $\begin{array}{c}0.010 \\
(0.223)\end{array}$ \\
\hline Variance risk premium, pct sq. & $\begin{array}{c}0.002 \\
(1.657)\end{array}$ & $\begin{array}{c}0.002 \\
(0.624)\end{array}$ & $\begin{array}{c}0.002^{* *} \\
(2.041)\end{array}$ \\
\hline European sovereign spread, pct & $\begin{array}{c}-0.014 \\
(-0.616)\end{array}$ & $\begin{array}{c}-0.050 \\
(-0.963)\end{array}$ & $\begin{array}{c}-0.038^{* *} \\
(-2.294)\end{array}$ \\
\hline Expected inflation, pct & $\begin{array}{c}0.007 \\
(0.246)\end{array}$ & $\begin{array}{c}0.085 \\
(0.808)\end{array}$ & $\begin{array}{c}0.021 \\
(0.909)\end{array}$ \\
\hline Low-grade bond spread, pct & $\begin{array}{c}0.019 \\
(0.610)\end{array}$ & $\begin{array}{c}0.032 \\
(1.363)\end{array}$ & $\begin{array}{l}0.037^{* * *} \\
(3.870)\end{array}$ \\
\hline News-based uncertainty index & $\begin{array}{l}-0.002^{* *} \\
(-2.544)\end{array}$ & $\begin{array}{l}-0.002^{* * *} \\
(-2.942)\end{array}$ & $\begin{array}{l}-0.002^{* * *} \\
(-4.356)\end{array}$ \\
\hline U.S. dollar exch. rate (broad) & $\begin{array}{c}0.002 \\
(0.383)\end{array}$ & $\begin{array}{c}0.015 \\
(1.069)\end{array}$ & $\begin{array}{c}-0.004 \\
(-1.355)\end{array}$ \\
\hline Bank $\times 10$-year Treas. rate, pct $\times$ Post- 2008 & & & $\begin{array}{l}-0.224^{* * *} \\
(-5.584)\end{array}$ \\
\hline Nonbank $\times 10$-year Treas. rate, pct $\times$ Post- 2008 & & & $\begin{array}{c}-0.147^{*} \\
(-1.959)\end{array}$ \\
\hline Post-2008 & & & $\begin{array}{l}1.362^{* * *} \\
(9.135)\end{array}$ \\
\hline Dummy for crisis quarters & & & $\begin{array}{c}-0.011 \\
(-0.153)\end{array}$ \\
\hline Lender type-year fixed effect & Yes & Yes & Yes \\
\hline Lender country-year fixed effect & Yes & Yes & Yes \\
\hline Borrower country-year fixed effect & Yes & Yes & Yes \\
\hline Num. of observ. & 14098 & 4672 & 20844 \\
\hline Num. of groups. & 1343 & 610 & 1563 \\
\hline Num. of clusters & 50 & 18 & 76 \\
\hline R-sq. within & 0.15 & 0.12 & 0.32 \\
\hline RMSE & 0.49 & 0.38 & 0.48 \\
\hline
\end{tabular}

$t$ statistics in parentheses. ${ }^{*} p<.1,{ }^{* *} p<.05,{ }^{* * *} p<.01$.

Note. The output shown is for regression models 4 and 5 that are modified to include lender type-specific regression coefficients. Based on U.S. dollar-denominated, U.S. dollar LIBOR-indexed term loans originated in the global market to non-U.S. borrowers on an ultimate counterparty basis. The number of observations is slightly lower than in Table 7 because nonfinancial lenders got excluded from the sample. Bank and Nonbank are dummy variables for banks and nonbank financial lenders respectively. Dependent variable is $\log$ (average spread of loan portfolio, pct) of lender $l$ from country $l, c$ of type $l, i$ made to borrowers from country $b, c$ in quarter $t$. Fixed effects not shown. Column (3) includes crisis quarters from 2007:Q3 to 2009:Q2. Errors clustered by quarters. 


\section{Appendix: Robustness checks}

In this appendix, we cover some robustness checks in detail and mention some others just in passing.

First, we note that while lenders and borrowers' risk management decisions are generally made at a parent level, some decisions to lend or borrow may be made on a local or immediate basis. To account for such a possibility, we reestimate regression models (2) to (5) on an immediate counterparty basis. That is, in these regressions, we do not consolidate immediate borrowers and lenders under their respective parents. The results for syndicate regressions in Table A1 are very similar to those on an ultimate counterparty basis in Table 4 but the results for portfolio regressions in Table $\mathrm{A} 2$ are weaker than those in Table 7 . The differences in statistical significance and explanatory power for portfolio regressions are not surprising because, again, risk management decisions tend to be made at a parent level. For example, on the supply side, a parent organization — for example, a bank or a bank holding companytypically allocates capital towards risky assets and sets limits on credit risk of such assets for its offices, agencies, or subsidiaries.

Second, we note that our findings do not necessarily apply to syndicated term loans made to borrowers with investment-grade debt ratings. In fact, omitting loans to such borrowers from the sample gives statistically stronger results. In a way, we offer a falsification test where the cost-of-funds and returns-on-safer-assets channels associated with lower interest rates do not generally apply to loans made to investment-grade borrowers.

Third, we note that the results are stronger for most active lenders in the global syndicated market. The lenders that lend in the global syndicated loan market in every quarter tend to be large, sophisticated institutions that cater syndicated loans to a wide range of nonbank lenders, but their number in our sample is very modest. 
Table A1: Syndicated regressions: Loans made by all lenders to non-U.S. borrowers on an immediate counterparty basis

\begin{tabular}{|c|c|c|c|}
\hline & $\begin{array}{c}(1) \\
\text { Pre-crisis }\end{array}$ & $\begin{array}{c}(2) \\
\text { Post-crisis }\end{array}$ & $\begin{array}{l}(3) \\
\text { Full }\end{array}$ \\
\hline Fed. funds rate, pct & $\begin{array}{l}-0.069^{* * *} \\
(-2.966)\end{array}$ & & $\begin{array}{l}-0.082^{\text {*** }} \\
(-4.504)\end{array}$ \\
\hline 10-year Treas. rate (z.c.), pct & $\begin{array}{c}0.075^{*} \\
(1.941)\end{array}$ & $\begin{array}{l}-0.110^{*} \\
(-1.927)\end{array}$ & $\begin{array}{c}0.044 \\
(1.122)\end{array}$ \\
\hline Variance risk premium, pct sq. & $\begin{array}{c}0.003^{*} \\
(1.810)\end{array}$ & $\begin{array}{c}-0.003 \\
(-0.739)\end{array}$ & $\begin{array}{c}0.001 \\
(0.506)\end{array}$ \\
\hline European sovereign spread, pct & $\begin{array}{c}0.030 \\
(1.086)\end{array}$ & $\begin{array}{l}-0.092^{* * *} \\
(-3.367)\end{array}$ & $\begin{array}{c}0.007 \\
(0.292)\end{array}$ \\
\hline Expected inflation, pct & $\begin{array}{l}-0.050 \\
(-1.183)\end{array}$ & $\begin{array}{l}0.156^{* *} \\
(2.478)\end{array}$ & $\begin{array}{c}0.055^{*} \\
(1.776)\end{array}$ \\
\hline Low-grade bond spread, pct & $\begin{array}{l}0.117^{* * *} \\
(2.768)\end{array}$ & $\begin{array}{l}0.114^{* * *} \\
(5.005)\end{array}$ & $\begin{array}{l}0.049^{* * *} \\
(3.352)\end{array}$ \\
\hline News-based uncertainty index & $\begin{array}{l}-0.004^{* * *} \\
(-4.228)\end{array}$ & $\begin{array}{l}-0.001^{*} \\
(-1.796)\end{array}$ & $\begin{array}{l}-0.001^{* * *} \\
(-3.299)\end{array}$ \\
\hline U.S. dollar exch. rate (broad) & $\begin{array}{c}0.008 \\
(1.072)\end{array}$ & $\begin{array}{l}0.027^{* *} \\
(2.795)\end{array}$ & $\begin{array}{l}0.011^{* * *} \\
(2.722)\end{array}$ \\
\hline Post-2008 × 10-year Treas. rate, pct & & & $\begin{array}{l}-0.022 \\
(-0.387)\end{array}$ \\
\hline Post-2008 & & & $\begin{array}{l}0.680^{* * *} \\
(2.767)\end{array}$ \\
\hline Dummy for crisis quarters & & & $\begin{array}{l}-0.078 \\
(-1.216)\end{array}$ \\
\hline Syndicate composition controls & Yes & Yes & Yes \\
\hline Lender type-year fixed effects & Yes & Yes & Yes \\
\hline Lender country-year fixed effects & Yes & Yes & Yes \\
\hline Borrower industry-year fixed effects & Yes & Yes & Yes \\
\hline Borrower country-year fixed effects & Yes & Yes & Yes \\
\hline Num. of observ. & 61269 & 18542 & 89207 \\
\hline Num. of clusters & 50 & 18 & 76 \\
\hline R-sq. w. & 0.39 & 0.37 & 0.47 \\
\hline RMSE & 0.26 & 0.15 & 0.27 \\
\hline \multicolumn{4}{|c|}{$\begin{array}{l}\text { statistics in parentheses. }{ }^{*} p<.1,{ }^{* *} p<.05,{ }^{* * *} p<.01 . \\
\text { Note. The output shown is for regressions } 2 \text { and } 3 \text {. Based on U.S. dollar- } \\
\text { denominated, U.S. dollar LIBOR-indexed term loans originated in the global } \\
\text { market to non-U.S. borrowers on an immediate basis. Dependent variable is } \\
\log (\text { loan spread, pct) of loan } j \text { in quarter } t \text { made to borrower } b \text { from country } \\
b, c \text { in industry } i \text { by lender } l \text { of type } l, i \text { from country } l, c \text {. Syndicate composi- } \\
\text { tion controls, including the number of lenders in each loan, and fixed effects } \\
\text { not shown. Column (3) includes crisis quarters from 2007:Q3 to 2009:Q2. } \\
\text { Errors clustered by quarters. }\end{array}$} \\
\hline
\end{tabular}


Table A2: Portfolio regressions: Portfolios of loans made by all lenders to non-U.S. borrowers on an immediate counterparty basis

\begin{tabular}{|c|c|c|c|}
\hline & $\begin{array}{c}(1) \\
\text { Pre-crisis }\end{array}$ & $\begin{array}{c}(2) \\
\text { Post-crisis }\end{array}$ & $\begin{array}{c}(3) \\
\text { Full }\end{array}$ \\
\hline Fed. funds rate, pct & $\begin{array}{c}-0.014 \\
(-1.185)\end{array}$ & & $\begin{array}{l}-0.030^{* * *} \\
(-3.073)\end{array}$ \\
\hline 10-year Treas. rate, pct & $\begin{array}{l}0.065^{* * *} \\
(3.078)\end{array}$ & $\begin{array}{l}-0.215^{* *} \\
(-2.275)\end{array}$ & $\begin{array}{l}0.063^{* * *} \\
(2.871)\end{array}$ \\
\hline Variance risk premium, pct sq. & $\begin{array}{c}0.002^{*} \\
(2.007)\end{array}$ & $\begin{array}{c}0.003 \\
(0.832)\end{array}$ & $\begin{array}{l}0.002^{* *} \\
(2.621)\end{array}$ \\
\hline European sovereign spread, pct & $\begin{array}{c}-0.016 \\
(-0.818)\end{array}$ & $\begin{array}{c}-0.031 \\
(-0.582)\end{array}$ & $\begin{array}{l}-0.033^{* *} \\
(-2.132)\end{array}$ \\
\hline Expected inflation, pct & $\begin{array}{c}-0.034 \\
(-1.144)\end{array}$ & $\begin{array}{c}0.122 \\
(1.018)\end{array}$ & $\begin{array}{c}0.029 \\
(1.074)\end{array}$ \\
\hline Low-grade bond spread, pct & $\begin{array}{c}0.014 \\
(0.597)\end{array}$ & $\begin{array}{c}0.010 \\
(0.441)\end{array}$ & $\begin{array}{l}0.031^{* * *} \\
(3.203)\end{array}$ \\
\hline News-based uncertainty index & $\begin{array}{l}-0.002^{* *} \\
(-2.456)\end{array}$ & $\begin{array}{l}-0.002^{* *} \\
(-2.795)\end{array}$ & $\begin{array}{l}-0.001^{* * *} \\
(-2.975)\end{array}$ \\
\hline U.S. dollar exch. rate (broad) & $\begin{array}{c}0.003 \\
(0.593)\end{array}$ & $\begin{array}{c}0.026 \\
(1.595)\end{array}$ & $\begin{array}{c}-0.003 \\
(-0.964)\end{array}$ \\
\hline Post-2008 × 10-year Treas. rate, pc & & & $\begin{array}{l}-0.237^{* * *} \\
(-5.658)\end{array}$ \\
\hline Post-2008 & & & $\begin{array}{c}1.514^{* * *} \\
(10.139)\end{array}$ \\
\hline Dummy for crisis quarters & & & $\begin{array}{c}0.027 \\
(0.347)\end{array}$ \\
\hline Lender type-year fixed effects & Yes & Yes & Yes \\
\hline Lender country-year fixed effects & Yes & Yes & Yes \\
\hline Borrower country-year fixed effects & Yes & Yes & Yes \\
\hline Num. of observ. & 25473 & 6947 & 35532 \\
\hline Num. of groups. & 4373 & 1559 & 5155 \\
\hline Num. of clusters & 50 & 18 & 76 \\
\hline R-sq. w. & 0.10 & 0.11 & 0.23 \\
\hline RMSE & 0.52 & 0.37 & 0.51 \\
\hline \multicolumn{4}{|c|}{$\begin{array}{l}t \text { statistics in parentheses. }{ }^{*} p<.1,{ }^{* *} p<.05,{ }^{* * *} p<.01 . \\
\text { Note. The output shown is for regressions } 4 \text { and } 5 \text {. Based on U.S. dollar- } \\
\text { denominated, U.S. dollar LIBOR-indexed term loans originated in the } \\
\text { global market to non-U.S. borrowers on an immediate basis. Dependent } \\
\text { variable is } \log \text { (average spread of loan portfolio, pct) of lender } l \text { from coun- } \\
\text { try } l, c \text { of type } l, i \text { made to borrowers from country } b, c \text { in quarter } t \text {. Fixed } \\
\text { effects not shown. Column (3) includes crisis quarters from 2007:Q3 to } \\
\text { 2009:Q2. Errors clustered by quarters. }\end{array}$} \\
\hline
\end{tabular}

